\title{
A Multi-Dimensional Analysis of Corporate Social Responsibility: Different Signals in Different Industries
}

\author{
Homayoon Shalchian ${ }^{1}$, Kais Bouslah ${ }^{2}$, Bouchra M'Zali ${ }^{3}$ \\ ${ }^{1}$ School of Commerce, Laurentian University, Sudbury, Canada \\ ${ }^{2}$ School of Management, University of St Andrews, St Andrews, UK \\ ${ }^{3}$ University of Quebec at Montreal, AICRI, CRSDD-ESG-UQAM, Montreal, Canada \\ Email: hshalchian@laurentian.ca, kbhb@st-andrews.ac.uk, mzali.bouchra@uqam.ca
}

Received 1 June 2015; accepted 27 June 2015; published 30 June 2015

Copyright (C) 2015 by authors and Scientific Research Publishing Inc.

This work is licensed under the Creative Commons Attribution International License (CC BY). http://creativecommons.org/licenses/by/4.0/

(c) (i) Open Access

\begin{abstract}
This study investigates the relation between individual dimensions of corporate social responsibility (CSR) and financial performance in different industries. Using Kinder, Lydenberg and Domini (KLD) social ratings, we find that investors seem to be more sensitive to the dimension "Environment" in mining and manufacturing sectors while they seem to be more sensitive to the dimension "Employees' welfare" in the service industry. Our results also suggest that investors perceive an additional financial risk from firm's irresponsible behavior and consequently, they are more pre-occupied by eventual losses caused by firms' social irresponsibility than by potential financial gains from corporate social performance.
\end{abstract}

\section{Keywords}

Corporate Social Performance, Corporate Social Irresponsibility, Financial Performance, Portfolio Management

\section{Introduction}

Corporate social responsibility (CSR) has become an important practice among corporations in recent years and a large number of institutional investors are showing a preference for investing in companies who consider social issues in their activities (El Ghoul et al., 2011; Guenster et al., 2010). The growing importance of CSR in public opinion has also encouraged many firms to report regularly their social involvement (Galema et al., 2008). "Corresponding author. 
On the demand side, major institutional investors from several countries signed the Principles for Responsible Investment (PRI) agreement in 2006 that aims to integrate social issues into investment decision-making (Bouslah et al., 2013). The rise of socially responsible practices has made corporate social performance (CSP) a popular field of study, but so far, empirical research has produced mixed results with regard to the relation social- financial performance (Shalchian et al., 2012). The divergence in results could be explained by conceptual and methodological differences but also by different measures of social performance (Tebini, 2012). For instance, Jones and Murrell (2001) and Derwall et al. (2005) consider CSP as a one-dimensional concept comprising only one aspect of corporate social performance such as environment or employees' welfare, whereas it is considered as a multi-dimensional concept when measured by Waddock and Graves (1997), Shalchian et al. (2012), and Bouslah et al. (2013).

At the methodological level, different selection criteria for the samples may also explain the inconsistency of the results. Several studies use sampled firms from one single industry (e.g. Moore, 2001; Simpson \& Kohers, 2002), while others, use multi-industry samples from diverse economic sectors (e.g. Kempf \& Osthoff, 2007; Shalchian et al., 2012). Griffin and Mahon (1997) argue that not only is industry an important factor to be considered in a study on the relation between social and financial performance but also different dimensions of social responsibility may have different levels of importance in different industries.

The divergence of results can also be explained by different approaches to the relation social-financial performance. A first approach, denoted positive approach, argues that social performance can improve the firm's image (Roman et al., 1999; Agle \& Caldwell, 1999). This improved image can, in turn, result in economic benefits including increased levels of investment into the firm. There is also a body of research suggesting a positive relation between social and financial performance through a negative approach (Hamilton, 1995; Frooman, 1997; Konar \& Cohen, 1997; Lanoie et al., 1998). Based on negative approach, CSP may be considered by investors as a positive signal concerning the future value of their investment but also as a means to avoid eventual losses caused by additional financial risk perceived by investors from firms' negative social actions or Corporate Social Irresponsibility (CSI).

In this paper, we pursue a double-objective. First, we consider individual dimensions of social performance and we analyze the relation between each dimension and financial performance separately in three different industries. Our first purpose is thus to dissociate different components of social performance in order to analyze their respective relations with financial performance in different industries. Second, we dissociate corporate social performance and corporate social irresponsibility in order to analyze their respective relations with financial performance in different industries. Our second purpose is therefore to verify whether investors, in their decision-making process, are more encouraged by positive social actions (strengths) or more preoccupied by additional financial risk caused by negative social actions (concerns) and their respective impacts on financial performance.

This paper is organized as follows. Section 2 presents the theoretical framework and research hypotheses. Section 3 and 4 describe respectively the data and methodology used in order to test our hypotheses. Section 5 presents our empirical results. Section 6 presents our conclusions.

\section{Theoretical Framework and Hypotheses}

\subsection{Corporate Social Performance and Financial Performance}

Although a large body of literature has examined the social-financial performance relation, the empirical evidence of this relation remains inconsistent. As pointed out by Tebini (2012), the conflicting results in prior studies are mainly attributable to differences in the approaches and methods used by the authors. The social-financial performance relation has also been studied from a "corporate" perspective as well as from a "portfolio" perspective.

From Neo-classical approach, social performance represents a burden for shareholders, while from the stakeholder's perspective CSP constitutes a signal to the market concerning the quality of the management (McGuire et al., 1988; Waddock \& Graves, 1997). Therefore, "A socially responsible firm may be perceived as being less prone to social crisis, and having better future positioning to be in compliance with regulations in social domains” (Bouslah et al., 2013). Table 1 summarizes different approaches to the social-financial performance relation.

From a corporate perspective, several studies investigate the social-financial performance relation focusing on 
Table 1. Organisational theories. The signs in the last three columns represent the expected relation between CSP and financial performance.

\begin{tabular}{|c|c|c|c|c|}
\hline Theory & Rationale & CSP & Strengths & Concerns \\
\hline Stakeholder theory (Freeman, 1984) & Good management & + & + & - \\
\hline Slack resources theory & Funds availability & + & + & - \\
\hline Risk management & CSP as insurance mechanism & + & + & - \\
\hline Reputation and investor base (Merton, 1987) & Investor’s preference & + & + & - \\
\hline Managerial opportunism & CSP as private benefits & - & - & + \\
\hline
\end{tabular}

Note: This table is based on Bouslah et al., 2013.

one single dimension of social responsibility of the firm while other studies consider aggregate measures of CSP (combination of several dimensions). Moreover, several studies examine the social-financial performance relation in one single industry while others use multi-industry samples. Table 2 summarizes the results of the studies on the social-financial performance relation at a corporate level.

Although, these results produce valuable information concerning the relation between CSP and financial performance, they do not take in consideration the specific factors that could affect firm's financial performance. A significant improvement to prior studies is brought by portfolio studies which consist of constructing diversified, mutually exclusive portfolios in order to compare the performance of portfolios of the most socially responsible firms, adjusted for systematic risk, with those of their conventional counterparts. Table 3 summarizes the results of the studies on the social-financial performance relation from portfolio perspective.

In their portfolio study, Yamashita et al. (1999) analyze firm's environmental performance and its relation with portfolio’s performance. Similarly, Derwall et al. (2005), constructing mutually exclusive portfolios and using the "Innovest” database, find a positive relation between firms' environmental performance and portfolio performance. Other studies consider multi-dimensional measures of CSP. For example, Kempf and Osthoff (2007) considering six dimensions of corporate social performance from KLD social ratings (community, diversity, employee relation, environment, human rights and product quality), find that investors can achieve their social and ethical goals without hurting their financial performance. Similarly, Shalchian et al. (2012), assuming that investors consider and grant the same importance to eight dimensions of CSP as rated by KLD, find a positive relation between social and portfolio performance. Moreover, some portfolio studies concentrate on specific industries while others analyze the relation between social and portfolio performance using a multi-industry sample. For instance, Cohen et al. (1997) using industry-controlled portfolio samples, find that there is no penalty in investing in "green portfolios”. Further, Derwall et al. (2005) using a multi-industry sample show that not only can benefits from CSP be substantial for investors but also that the results are industry-sensitive. Griffin and Mahon (1997) suggest that not only is industry an important factor to be taken in consideration in a study on social-financial performance relation, but also the industry must be considered as a control variable. Reinforcing this point, Shalchian et al. (2012), subdividing their sample based on SIC codes, analyze the relation between CSP and portfolio performance through six different industries. Their results suggest the existence of different relations between social and portfolio performances in different industries.

\subsection{Dimensions, Industries and the Relation Social-Financial Performance}

Bouslah et al. (2013) argue that most previous studies use aggregate measures combining several dimensions of CSP which are not equally important for investors. Griffin and Mahon (1997) suggest that different dimensions of CSP are not equally important and relevant and aggregation may confound the individual impact of each dimension on financial performance. Similarly, Rojas et al. (2009) argue that activist investors seem to grant different levels of importance to different dimensions of CSP. For example, environment seemed to be the most important dimension of CSP for activist investors in 1990s while human rights became the most relevant issue in 2001. Further, Mattingly and Berman (2006) suggest that positive and negative social actions are conceptually distinct construct and should not be combined. This strongly suggests that not only each dimension of CSP must be considered individually (Hillman \& Keim, 2001; Rehbein et al., 2004), but also positive and negative social actions must be dissociated and their respective relations with financial performance should be analyzed separately. 
Table 2. Social-financial relation from corporate perspective.

\begin{tabular}{|c|c|c|}
\hline Industry/dimension & Single-dimension & Multi-dimension \\
\hline Single-industry & $\begin{array}{l}\text { Simpson and Kohers (2002): Community involvement } \\
\text { from CRA ratings in Banking industry }(+)^{1}\end{array}$ & $\begin{array}{l}\text { Moore (2001): EIRIS ratings in Supermarket } \\
\text { industry }(-)^{2}\end{array}$ \\
\hline Multi-industry & $\begin{array}{l}\text { Carter et al. (2000): Environmental ratings from } \\
\text { EPINDEX }(+)^{3} \\
\text { Jones and Murrell (2001): Employees welfare from } \\
\text { Working mother magazine's survey }(+)^{4}\end{array}$ & $\begin{array}{l}\text { Chung et al. (2003): Fortune magazine's } \\
\text { reputation index }(+)^{5} \\
\text { Vance (1975): Moskowitz social ratings }(-) \\
\text { Waddock and Graves (1997): KLD ratings }(+)^{6}\end{array}$ \\
\hline
\end{tabular}

Note: (+): Positive relation between CSP and CFP. (-): Negative relation between CSP and CFP.

Table 3. Social-financial relation from portfolio perspective.

\begin{tabular}{|c|c|c|}
\hline Industry/dimension & Single-dimension & Multi-dimension \\
\hline Single-industry & Cohen et al. (1997): Environment from TRI (0) ${ }^{7}$ & $\begin{array}{l}\text { Shalchian et al. (2012): KLD social } \\
\text { ratings. }(+)\end{array}$ \\
\hline Multi-industry & $\begin{array}{l}\text { Derwall et al. (2005): Environmental ratings from Innovest }(+)^{8} \\
\text { Yamashita et al. (1999): Environmental ratings from CEP }(+)^{9}\end{array}$ & $\begin{array}{l}\text { Aslaksen and Synnestvedt (2003): (0) } \\
\text { Kempf and Osthoff (2007): KLD social } \\
\text { ratings (+) } \\
\text { Diltz (1995): (+): CEP } \\
\text { Shalchian et al. (2012): KLD social } \\
\text { ratings. (+) }\end{array}$ \\
\hline
\end{tabular}

Note: (+): Positive relation between CSP and CFP. (-): Negative relation between CSP and CFP. (0): No significant relation between CSP and CFP.

Reinforcing this point, Bouslah et al. (2013) analyze the relation between individual dimensions of CSP and firm's risk and show that not all CSP dimensions are relevant for firm risk. Their result show that for S\&P 500 firms, dimensions such as Employees' welfare, Governance and Community involvement affect negatively firms' risk while for non S\&P 500 firms, Environment, Employees' welfare and Community involvement affect negatively firms' risk. Similarly, El Ghoul et al. (2011) analyze the relation between several dimensions of CSP (environmental policies, employee relation and product policies) and cost of equity. Their results suggest that firms with socially responsible practices have higher valuation, lower risk, and consequently, lower cost of capital.

It has also been argued in the literature, that different dimensions of social responsibility may have different relations with financial performance in different industries: "Different industries face different configurations of stakeholders with differing degrees of activism on issues" (Griffin \& Mahon, 1997). Therefore, a company operating in mining industry may be considered as socially responsible when the managers take the necessary measures to avoid pollution of the environment while a company in service industry may be considered as socially responsible because of another dimension of CSP (e.g. employees' welfare or community involvement). In other words, in different industries and based on firms' nature of activities, the relation social-financial performance may have different levels of sensitivity to different dimensions of CSP.

Walker and Howard (2002) outline several reasons why "environment" seems to be an important dimension of CSP in the mining sector. First, they argue that the public has often a negative opinion of mining companies

\footnotetext{
${ }^{1}$ CRA (Community re-investment Act) was passed to ensure that commercial banks meet the credit needs of the market where they hold public charters to do business, especially the needs of low income customers. CRA's ratings summarize the degree of compliance into 4 categories: 1) Outstanding, 2) Satisfactory, 3) Needs to improve, 4) Substantial non compliance.

${ }^{2}$ EIRIS: Ethical Investment Research Services.

${ }^{3}$ EPINDEX is composed of weighted average of 6 environmental items based on the surveys from firms' managers.

${ }^{4}$ Working mother magazine ranks "most family-friendly" companies.

${ }^{5}$ Fortune magazine social rating includes eight social attributes: quality of management, quality of products and services, innovativeness, value of long-term investment, soundness of financial position, ability to attract, develop and keep talented people, responsibility to the community and environment, and wise use of corporate assets.

${ }^{6}$ MSCI ESG STATS (former KLD Research \& Analytical Inc) rates eight dimensions of social responsibility. For simplicity, we use the KLD abbreviation.

${ }^{7}$ Toxic Release Inventory (TRI) was created as part of emergency planning and community right-to-know Act in 1986. Under the Act, state is required to collect data on release of certain toxic chemicals from divers industries and make them available to the public.

${ }^{8}$ Innovest is a measure of Eco-efficiency that measures firms' environmental performance.

${ }^{9} \mathrm{CEP}$ (Council of Economic Priorities) evaluates large companies' environmental performance based on several criteria such as: environmental goals, use of recycled material, energy conservation, environmental technology, etc.
} 
and their respect for the environment. Second, the financial sector is often focused on mining sector's environmental performance and mining companies are frequently screened out by socially responsible mutual funds. Third, environmental and other pressure groups have consistently challenged mining companies' projects and expressed concerns about their activities. An example of these concerns is the numerous oppositions of environmental groups to the projects of pipelines between Alberta and Southern U.S. and between Alberta and Eastern Canada. Other studies point out the importance of not only environmental performance but also other dimensions of CSP in the mining sector. For instance, Yakovleva (2005) discusses the importance of the mining industry's progress towards sustainable development and evaluates the practices of mining companies with respect to several dimensions of corporate social responsibility: environment, health and safety, employees' welfare and community involvement. Similarly, Jenkins and Yakovleva (2006) argue that, for the mining industry, CSP consists of not only protecting the environment but also of meeting the demands of communities and responding to different stakeholders including employees. They present Newmont Corporation as an example of the concerns about different dimensions of CSP in mining industry and its activities. The company had to suspend its operations in Peru after concerns were raised about their lack of community involvement, pollution and related impacts on community's health and insufficient job creation for local community. These arguments lead to three hypotheses:

H1: The relation social-financial performance in mining industry is more sensitive to the dimension "environment".

H2: The relation social-financial performance in mining industry is more sensitive to the dimension "employees' welfare”.

H3: The relation social-financial performance in mining industry is more sensitive to the dimension "community involvement”.

Further, Konar and Cohen (2001) show that poor environmental performance has a significantly negative effect on the value of the intangible-assets of publicly traded manufacturing firms included in S\&P 500 and consequently on firms' market values. Other studies use multi-dimensional measures of social performance. For example, Lin et al. (2009) choose social criteria such as: commitment to social governance, open dialogue with external stakeholders and environmental sustainability. Dividing their sample into manufacturing and nonmanufacturing companies, they show that social responsibility has a more significant effect on financial performance in manufacturing industry. Similarly, Heinze et al. (1999), using Fortune’s “America’s most admired companies" find a positive relation between firms' ethical behavior and profitability in 22 manufacturing groups. Their results however show that the relation social-financial performance is not uniform from one product group to another. It is also not unusual for companies in manufacturing industry to be granted different ratings by the KLD for different dimensions of CSP. For instance, concerns had been raised about NIKE with respect to employees' welfare since 1990s. However, in 2006 the company was rated zero by KLD for employees' welfare (1 strength and 1 concern), positively for environment (3 strengths and 0 concerns) and positively for community involvement ( 3 strengths and 0 concerns). These arguments and observations lead to the following hypotheses:

H4: The relation social-financial performance in manufacturing industry is more sensitive to the dimension "environment".

H5: The relation social-financial performance in manufacturing industry is more sensitive to the dimension "employees' welfare".

H6: The relation social-financial performance in manufacturing industry is more sensitive to the dimension "community involvement".

Concerning the service industry, the sector shows some specific characteristics. First, given the service firms' nature of activities and the growing demand for services, the industry is labor intensive and creates most of the employment in developed countries. Second, the progress of technology in agricultural and manufacturing sectors in industrialized countries has caused a decline of demand for labor in these sectors and consequently, the labor force has moved massively to service industry during past decades. This strongly suggests that employees' welfare might be an important dimension of social responsibility in service industry. However, it is not unusual for service companies to be rated negatively by KLD for employees' welfare but positively for another dimension of CSP. For instance, Sears Corporation was rated negatively for employees' welfare ( 0 strength, 3 concerns), positively for community involvement ( 1 strength, 0 concern) and negatively for environment ( 0 strength, 1 concern) in 2006. Further, Calabrese and Lancioni (2008) define corporate social responsibility in the service industry as “firm's commitment to its employees and customers". Their results however suggest that firms' 
commitment to their employees might negatively affect their relation with customers. These arguments and observations lead to the following hypotheses:

H7: The relation social-financial performance in service industry is more sensitive to the dimension "environment".

H8: The relation social-financial performance in service industry is more sensitive to the dimension "employees' welfare".

H9: The relation social-financial performance in service industry is more sensitive to the dimension "community involvement".

\section{Data}

We obtain our data (stockprices and market capitalizations) from Compustat from January 1991 to December 2009. Further, we use MSCI ESG STAT (formerly KLD Research \& Analytics Inc) to proxy for corporate social performance during the same period. KLD analyzes eight dimensions of corporate social responsibility: environment, employee welfare, community involvement, corporate governance, diversity, human rights, product quality, and exclusionary screens. ${ }^{10}$ KLD'sanalysts use several quantitative and qualitative criteria in order to evaluate the "Strength" (positive social action) and "Concerns" (negative social actions) for each dimension of social responsibility. Furthermore, KLD's analysts evaluate a relatively large number of American corporations in various industries that are published annually. This allows us to divide the sample according to the nature of activity and consequently, analyze the relation between different dimensions of social performance and financial performance across several economic sectors. The total number of companies rated by KLD database has increased to approximately 2900 in 2009.

\section{Method}

Our method consists of classifying U.S. companies based on KLD social ratings respectively for three dimensions of CSP (environment, employees' welfare and community involvement) and in three different sectors of activity (mining, manufacturing and services) in order to construct "best-in-class" value-weighted portfolios with the highest $25 \%$ of companies and "worst-in-class" value-weighted portfolios with the lowest $25 \%$ of companies. Further, we compare, in each industry and based on each dimension, best-in-class portfolios' financial performances with those of their worst-in-class counterparts. Therefore, we start by constructing three industries (industry A, B and C) based on companies' nature of activities:

Industry A: We regroup all companies with SIC codes 1000 to 1499 (Mining and Chemicals) and we add to this group all companies with SIC codes from 2800 to 2899 (Manufacturing chemicals) and those with SIC codes from 2900 to 2999 (Petroleum products and coal).

Industry B: We regroup all companies with SIC codes from 2000 to 3999 (Manufacturing industry) and we remove all companies with SIC codes from 2800 to 2899 (Manufacturing chemicals) and those with SIC codes from 2900 to 2999 (Petroleum products and coal) from this group.

Industry C: We regroup all companies with SIC codes from 5100 to 5299 (Whole sales industry), from 5300 to 5999 (Retail industry) and from 7000 to 8999 (Service industry).

In each industry, we estimate the KLD ratings for each of the three dimensions of social responsibility for all companies. The companies' ratings for each dimension consist of the average strength minus the average concerns for that dimension. Therefore, we suppose that investors take individual dimensions of CSP into consideration separately in their decision-making process. Further, in each industry and based on each dimension, we consider two mutually exclusive, value-weighted portfolios (high ranked and low ranked) denoted respectively best-in-class and worst-in-class portfolios. The best-in-class (worst-in-class) portfolio consists of companies making up the highest (lowest) 25\% as rated for each dimension by KLD. We thus construct, in each industry, "environment-sorted", "employee-sorted" and "community-sorted" portfolios.

We also suppose that the investors, in their decision-making process, rebalance their portfolios once every year, based on KLD's ratings for each dimension and in each sector of activity. Therefore, in each industry, we assume that in the beginning of the year, if a company is rated among the best $25 \%$ for one of the dimensions (e.g. environment), it will be included in the best-in-class (environment-sorted) portfolio. In the beginning of the

\footnotetext{
${ }^{10}$ Exclusionary screens consists of "negative ratings" by KLD for all companies involved in the production of tobacco, alcohol, gambling, nuclear and firearms.
} 
following year, if the same company is not among the best $25 \%$ for the same dimension, it will be excluded and replaced by another company.

Once all portfolios are formed, we use the Carhart (1997) four-factor regression model respectively on environment-sorted, employee-sorted and community sorted portfolios in the three industries:

$$
R_{i, t}-R_{f, t}=\alpha_{i}+\beta_{i, 1}\left(R_{m, t}-R_{f, t}\right)+\beta_{i, 2} S M B_{t}+\beta_{i, 3} H M L_{t}+\beta_{i, 4} P Y 1 Y R_{t}+\varepsilon_{i, t}
$$

where the dependant variable, $R_{i, t}-R_{f, t}$ is the monthly excess return on portfolio $i$ over the risk-free rate in month $t$. The independent variables are the returns of the four zero-investment factor portfolios. $R_{m, t}-R_{f, t}$ denotes the excess return of the market portfolio over the risk-free rate, SMB (Small minus Big) is the difference between the return of a portfolio of small-cap stocks minus the return of a portfolio of large-cap stocks, $H M L$ (High minus Low) is the difference between the return of a portfolio of "value stocks" minus the return of a portfolio of "growth stocks". The Momentum factor PR1YR is constructed as the equal-weight average of firms with the highest eleven-month returns lagged one month minus the equal-weight average of firms with the lowest eleven-month returns lagged one month. The error term in the regression is $\varepsilon_{i, t}$. We use Fama and French's (1993) market proxy as a relevant benchmark. The intercept $(\alpha)$ is an indicator of a performance differential between the two types of investment.

Moreover, Shalchian et al. (2012) showed that the relation social-financial performance can be affected by different market tendencies (bullish or bearish market) and consequently, by the changes of market conditions in different periods. In this study, we examine the impact of the internet crisis and the credit crisis on the relation social-financial performance using 2 dummy variables:

$$
R_{i, t}-R_{f, t}=\alpha_{i}+\beta_{i, 1}\left(R_{m, t}-R_{f, t}\right)+\beta_{i, 2} S M B_{t}+\beta_{i, 3} H M L_{t}+\beta_{i, 4} P Y 1 Y R_{t}+\beta_{i, 5} D_{1, t}+\beta_{i, 6} D_{2, t}+\varepsilon_{i, t}
$$

where the first four factors are the same as in the prior model and the factors $D_{1, t}$ and $D_{2, t}$ are dummy variables that will be equal to 1 for the period of internet and credit crises and 0 otherwise. We consider the period April 2000-September 2002 as internet crisis period and July 2007-February 2009 as financial crisis period.

Finally, we compare the positive effect of social performance and the negative effect of social irresponsibility on financial performance. Therefore, we begin by classifying the companies once based on "average strength" and once based on "average concerns" for each dimension in each year. In other words, we suppose that investors, in their decision-making process, take into consideration strengths (positive social actions) and concerns (negative social actions) separately. Further, we construct mutually exclusive portfolios with distinctive social ratings based on average strengths and average concerns for each dimension and in each industry. Based on average strength, the best-in-class (worst-in-class) portfolio consists of companies making up the highest (lowest) $25 \%$ as rated for strengths for each dimension by KLD. Based on average concerns, the best-in-class (worstin-class) portfolio consists of companies making up the lowest (highest) $25 \%$ as rated for concerns for each dimension by KLD. Once all "Strength-sorted" and "Concern-sorted" portfolios are formed for the three dimensions and in the three industries, we use the Carhart (1997) four-factor regression model to compare the abnormal returns of best-in-class portfolios with those of worst-in-class portfolios.

\section{Results}

\subsection{The Relation between Different Dimensions of Social Performance and Industry-Sorted Portfolios Performance}

Table 4 summarizes descriptive statistics for our socially-ranked portfolios for the 1991-2009 period. The table shows that, except for community-sorted portfolios in industry B and environment and community-sorted portfolios in industry $\mathrm{C}$, best-in-class portfolios have a higher average return than their worst-in-class counterparts. The average returns for environment-sorted best-in-class portfolios in industries A and B are respectively $10.80 \%$, and $15.60 \%$, while they are $9.60 \%$ in industry A and $12.00 \%$ in industry B for environment-sorted worst-in-class portfolios. In most cases, Sharpe ratios are higher for best-in-class portfolios. Therefore, the results show that even after adjusting for volatility, best-in-class portfolios perform better in most cases than their worst-in-class counterparts. The $4^{\text {th }}$ and $5^{\text {th }}$ columns of Table 1 (skewness and Kurtosis) indicate only weak deviations from a normal distribution. Overall, our primary results suggest that the gaps between portfolios excess returns adjusted for total risk are in favour of high-ranked portfolios.

Table 5 shows performance evaluation results using Carhart (1997) four-factor model in industry "A" (Mining 
Table 4. Descriptive Statistics for socially-ranked portfolios, January 1991 to December 2009. The Best-in-class and the Worstin-class portfolios represent respectively the high-ranked and the low-ranked portfolios, according to KLD social ratings.

\begin{tabular}{|c|c|c|c|c|c|}
\hline Portfolio & Mean (\%) & Std. Dev (\%) & Sharpe ratio & Skewness & Kurtosis \\
\hline \multicolumn{6}{|l|}{ Industry A } \\
\hline Best-in-class (environment) & 10.80 & 14.89 & 0.73 & -0.46 & 3.83 \\
\hline Worst-in-class (environment) & 9.60 & 16.28 & 0.59 & -0.59 & 3.96 \\
\hline Best-in-class (employee) & 12.10 & 14.55 & 0.83 & -0.21 & 3.19 \\
\hline Worst-in-class (employee) & 12.00 & 16.28 & 0.74 & -0.29 & 5.43 \\
\hline Best-in-class (community) & 10.80 & 13.86 & 0.78 & -0.38 & 3.43 \\
\hline Worst-in-class (community) & 12.00 & 16.30 & 0.76 & -0.29 & 3.72 \\
\hline \multicolumn{6}{|l|}{ Industry B } \\
\hline Best-in-class (environment) & 15.60 & 21.13 & 0.74 & -0.41 & 4.37 \\
\hline Worst-in-class (environment) & 12.00 & 19.05 & 0.63 & -0.08 & 7.76 \\
\hline Best-in-class (employee) & 14.40 & 18.71 & 0.77 & -0.21 & 3.19 \\
\hline Worst-in-class (employee) & 14.40 & 20.78 & 0.69 & -0.65 & 5.68 \\
\hline Best-in-class (community) & 12.00 & 18.01 & 0.67 & -0.41 & 4.37 \\
\hline Worst-in-class (community) & 18.00 & 18.71 & 0.96 & -0.25 & 4.33 \\
\hline \multicolumn{6}{|l|}{ Industry C } \\
\hline Best-in-class (environment) & 12.00 & 21.82 & 0.55 & 0.11 & 3.93 \\
\hline Worst-in-class (environment) & 18.00 & 25.98 & 0.69 & 0.80 & 5.73 \\
\hline Best-in-class (employee) & 13.20 & 21.82 & 0.60 & -0.31 & 3.66 \\
\hline Worst-in-class (employee) & 9.60 & 16.63 & 0.58 & -0.45 & 3.87 \\
\hline Best-in-class (community) & 9.60 & 20.44 & 0.47 & 0.28 & 5.07 \\
\hline Worst-in-class (community) & 13.20 & 22.52 & 0.59 & 0.17 & 5.17 \\
\hline
\end{tabular}

Table 5. Empirical results of four-factor regressions in Industry A, January 1991 to December 2009. Best-in-class and the worst-in-class portfolios represent respectively high-ranked and low-ranked portfolios according to KLD social ratings in each industry. $T$-statistics are in parenthesis. Sample alphas are annualized percentages. The regressions use Newey-West (1987) heteroskedasticity and autocorrelation consistent standard errors to calculate the significance levels for all coefficients.

\begin{tabular}{|c|c|c|c|c|c|c|}
\hline Portfolio & $\alpha(\%)$ & $R_{m}-R_{f}$ & $S M B$ & $H M L$ & PY1YR & $\operatorname{Adj} R^{2}$ \\
\hline $\begin{array}{l}\text { Best-in-class } \\
\text { (environment) }\end{array}$ & $\begin{array}{l}7.20^{* * *} \\
(2.57)\end{array}$ & $\begin{array}{l}0.70^{* * *} \\
(9.54)\end{array}$ & $\begin{array}{l}-0.40^{* * *} \\
(-6.52)\end{array}$ & $\begin{array}{l}0.19^{*} \\
(1.78)\end{array}$ & $\begin{array}{c}0.06 \\
(1.14)\end{array}$ & 0.47 \\
\hline $\begin{array}{l}\text { Worst-in-class } \\
\text { (environment) }\end{array}$ & $\begin{array}{l}4.80^{* * *} \\
(3.16)\end{array}$ & $\begin{array}{l}0.69^{* * *} \\
(8.97)\end{array}$ & $\begin{array}{l}-0.39^{* * * *} \\
(-4.21)\end{array}$ & $\begin{array}{l}0.20^{*} \\
(1.76)\end{array}$ & $\begin{array}{c}0.04 \\
(0.48)\end{array}$ & 0.40 \\
\hline Difference PF & $\begin{array}{c}2.40 \\
(0.94)\end{array}$ & $\begin{array}{c}0.01 \\
(0.01)\end{array}$ & $\begin{array}{c}-0.01 \\
(-0.09)\end{array}$ & $\begin{array}{c}-0.01 \\
(-0.09)\end{array}$ & $\begin{array}{c}0.02 \\
(0.18)\end{array}$ & 0.03 \\
\hline $\begin{array}{l}\text { Best-in-class } \\
\text { (employee) }\end{array}$ & $\begin{array}{l}7.20^{* * *} \\
(3.78)\end{array}$ & $\begin{array}{l}0.75^{* * *} \\
(9.14)\end{array}$ & $\begin{array}{l}-0.40^{* * *} \\
(-6.51)\end{array}$ & $\begin{array}{c}0.10 \\
(0.99)\end{array}$ & $\begin{array}{c}0.04 \\
(0.80)\end{array}$ & 0.58 \\
\hline $\begin{array}{l}\text { Worst-in-class } \\
\text { (employee) }\end{array}$ & $\begin{array}{l}6.00^{* *} \\
(2.51)\end{array}$ & $\begin{array}{l}0.82^{* * *} \\
(11.37)\end{array}$ & $\begin{array}{l}-0.15^{* *} \\
(-2.15)\end{array}$ & $\begin{array}{l}0.33^{* * *} \\
(3.35)\end{array}$ & $\begin{array}{c}-0.01 \\
(-0.09)\end{array}$ & 0.52 \\
\hline Difference PF & $\begin{array}{l}1.20 \\
(0.27)\end{array}$ & $\begin{array}{c}-0.07 \\
(-0.82)\end{array}$ & $\begin{array}{l}-0.25^{* * *} \\
(-2.66)\end{array}$ & $\begin{array}{l}-0.23^{* *} \\
(-1.99)\end{array}$ & $\begin{array}{c}0.05 \\
(0.02)\end{array}$ & 0.02 \\
\hline $\begin{array}{l}\text { Best-in-class } \\
\text { (community) }\end{array}$ & $\begin{array}{l}7.20^{* * *} \\
(4.08)\end{array}$ & $\begin{array}{l}0.63^{* * *} \\
(7.75)\end{array}$ & $\begin{array}{l}-0.47^{* * *} \\
(-7.25)\end{array}$ & $\begin{array}{c}0.04 \\
(0.39)\end{array}$ & $\begin{array}{c}0.05 \\
(0.84)\end{array}$ & 0.49 \\
\hline $\begin{array}{l}\text { Worst-in-class } \\
\text { (community) }\end{array}$ & $\begin{array}{l}7.20^{* * *} \\
(3.72)\end{array}$ & $\begin{array}{l}0.78^{* * *} \\
(10.71)\end{array}$ & $\begin{array}{l}-0.38^{* * *} \\
(-4.06)\end{array}$ & $\begin{array}{c}0.18 \\
(1.38)\end{array}$ & $\begin{array}{c}0.05 \\
(0.69)\end{array}$ & 0.50 \\
\hline Difference PF & $\begin{array}{c}0.00 \\
(0.17)\end{array}$ & $\begin{array}{l}-0.15^{*} \\
(-1.89)\end{array}$ & $\begin{array}{c}-0.09 \\
(-0.67)\end{array}$ & $\begin{array}{c}-0.14 \\
(-0.97)\end{array}$ & $\begin{array}{c}0.00 \\
(1.41)\end{array}$ & 0.63 \\
\hline
\end{tabular}

Note: ${ }^{*}$ Significant at the 10 percent level. ${ }^{* *}$ Significant at the 5 percent level. ${ }^{* * *}$ Significant at the 1 percent level. 
and chemicals). As the primary focus of our research is the performance differential between the best-in- class and worst-in-class portfolios, we provide the "difference" portfolios. The impact of social screening for each dimension of CSP on investment performance is the difference between the intercepts of the best-in-class and worst-in-class portfolios. First, we note that the abnormal returns of best-in-class portfolios in industry " $\mathrm{A}$ " are not significantly higher than those of worst-in-class portfolios for any of the three dimensions of CSP. Second, the coefficients betas reveal that, except for community-sorted portfolios, there was no significant difference between portfolios in exposure to the market risk factor. Moreover, the differences of the intercepts show that, except for community-sorted portfolios, best-in-class portfolios provide higher abnormal returns than their worst-in-class counterparts. The differences of abnormal returns are $2.40 \%$ for environment-sorted and $1.20 \%$ for employee-sorted portfolios. According to $t$-statistics, however, the differences are not statistically significant.

Table 6 shows performance evaluation results using Carhart (1997) four-factor model in industry "B" (Manufacturing industry). First, we note a difference of the average annual return in favour of best-in-class portfolios for environment and employees' welfare (7.20\% for environment-sorted portfolios and $1.20 \%$ for employee-sorted portfolios). Further, we note that the difference is statistically significant at $10 \%$ for environment-sorted portfolios. This result confirms those of Konar and Cohen (2001) who suggested that environment seems to be an important dimension of CSP in manufacturing industry. Indeed, environment-sorted portfolios' abnormal returns exhibit a significant difference in favour of social investment in manufacturing sector. Second, we note that factor loading on $R m-R f, S M B$ and $H M L$ is mainly significant. The results show differences of $H M L$ of -0.92 and -0.21 respectively for environment-sorted and employee-sorted portfolios. According tot-statistics, the results are statistically significant at the $1 \%$ level. Moreover, the factor loading on $H M L$ suggests that bestin-class (environment and employee-sorted) portfolios in manufacturing industry tend towards growth-stock while their worst-in-class counterparts tend towards value-stock. Finally, the results on $H M L$ also suggest that best-in-class portfolios were significantly tilted toward smanufacturing companies who have experienced previous financial success.

Table 7 presents the performance estimates in industry C (Service industry). First, we note that for the environment and community-sorted portfolios, average factor-adjusted annual returns are not significantly higher than their worst-in-class counterparts. Further, we notice that for employee-sorted portfolios the gap between

Table 6. Empirical results of four-factor regressions in Industry B, January 1991 to December 2009. Best-in-class and the worst-in-class portfolios represent respectively high-ranked and low-ranked portfolios according to KLD social ratings in each industry. T-statistics are in parenthesis. Sample alphas are annualized percentages. The regressions use Newey-West (1987) heteroskedasticity and autocorrelation consistent standard errors to calculate the significance levels for all coefficients.

\begin{tabular}{|c|c|c|c|c|c|c|}
\hline Portfolio & $\alpha(\%)$ & $R_{m}-R_{f}$ & $S M B$ & $H M L$ & $P Y 1 Y R$ & $\operatorname{Adj} R^{2}$ \\
\hline $\begin{array}{l}\text { Best-in-class } \\
\text { (environment) }\end{array}$ & $\begin{array}{c}10.80^{* * *} \\
(4.29)\end{array}$ & $\begin{array}{l}1.02^{* * *} \\
(23.35)\end{array}$ & $\begin{array}{c}0.03 \\
(0.36)\end{array}$ & $\begin{array}{l}-0.34^{* * *} \\
(-5.38)\end{array}$ & $\begin{array}{l}-0.15^{* *} \\
(-2.50)\end{array}$ & 0.73 \\
\hline $\begin{array}{l}\text { Worst-in-class } \\
\text { (environment) }\end{array}$ & $\begin{array}{l}3.60^{*} \\
(1.77)\end{array}$ & $\begin{array}{l}1.02^{* * *} \\
(22.06)\end{array}$ & $\begin{array}{c}0.02 \\
(0.27)\end{array}$ & $\begin{array}{l}0.58^{* * *} \\
(5.98)\end{array}$ & $\begin{array}{l}-0.19^{* * *} \\
(-2.74)\end{array}$ & 0.77 \\
\hline Difference PF & $\begin{array}{l}7.20^{*} \\
(1.91)\end{array}$ & $\begin{array}{c}0.00 \\
(0.01)\end{array}$ & $\begin{array}{c}0.01 \\
(0.11)\end{array}$ & $\begin{array}{l}-0.92^{* * *} \\
(7.27)\end{array}$ & $\begin{array}{l}-0.34 \\
(0.36)\end{array}$ & 0.37 \\
\hline $\begin{array}{l}\text { Best-in-class } \\
\text { (employee) }\end{array}$ & $\begin{array}{l}8.40^{* * *} \\
(4.88)\end{array}$ & $\begin{array}{l}1.07^{* * *} \\
(35.09)\end{array}$ & $\begin{array}{l}0.10^{* *} \\
(2.07)\end{array}$ & $\begin{array}{l}-0.30^{* * *} \\
(-5.41)\end{array}$ & $\begin{array}{l}-0.08^{* * *} \\
(-2.75)\end{array}$ & 0.80 \\
\hline $\begin{array}{l}\text { Worst-in-class } \\
\text { (employee) }\end{array}$ & $\begin{array}{l}7.20^{* * *} \\
(3.56)\end{array}$ & $\begin{array}{l}1.01^{* * *} \\
(22.60)\end{array}$ & $\begin{array}{l}0.20^{* * *} \\
(3.25)\end{array}$ & $\begin{array}{c}0.09 \\
(1.03)\end{array}$ & $\begin{array}{c}-0.14^{* * *} \\
(-4.19)\end{array}$ & 0.80 \\
\hline Difference PF & $\begin{array}{l}1.20 \\
(0.54)\end{array}$ & $\begin{array}{c}0.06 \\
(1.00)\end{array}$ & $\begin{array}{l}-0.10 \\
(-1.32)\end{array}$ & $\begin{array}{c}-0.21^{* * *} \\
(-3.72)\end{array}$ & $\begin{array}{l}-0.22 \\
(1.14)\end{array}$ & 0.14 \\
\hline $\begin{array}{l}\text { Best-in-class } \\
\text { (community) }\end{array}$ & $\begin{array}{l}7.20^{* * *} \\
(3.55)\end{array}$ & $\begin{array}{l}0.91^{* * *} \\
(17.04)\end{array}$ & $\begin{array}{c}0.08 \\
(1.20)\end{array}$ & $\begin{array}{l}-0.11^{* *} \\
(-2.48)\end{array}$ & $\begin{array}{l}-0.17^{* * *} \\
(-3.92)\end{array}$ & 0.78 \\
\hline $\begin{array}{l}\text { Worst-in-class } \\
\text { (community) }\end{array}$ & $\begin{array}{l}9.60^{* * *} \\
(3.58)\end{array}$ & $\begin{array}{l}1.08^{* * *} \\
(31.64)\end{array}$ & $\begin{array}{c}0.00 \\
(0.05)\end{array}$ & $\begin{array}{c}0.08 \\
(0.68)\end{array}$ & $\begin{array}{c}0.02 \\
(0.47)\end{array}$ & 0.75 \\
\hline Difference PF & $\begin{array}{l}-2.40 \\
(-0.91)\end{array}$ & $\begin{array}{l}-0.17^{* *} \\
(-2.40)\end{array}$ & $\begin{array}{c}0.08 \\
(0.88)\end{array}$ & $\begin{array}{l}-0.19 \\
(-1.33)\end{array}$ & $\begin{array}{c}-0.19^{* * *} \\
(-2.69)\end{array}$ & 0.08 \\
\hline
\end{tabular}

Note: ${ }^{*}$ Significant at the 10 percent level. ${ }^{* *}$ Significant at the 5 percent level. ${ }^{* * *}$ Significant at the 1 percent level. 
Table 7. Empirical results of four-factor regressions in Industry C, January 1991 to December 2009. Best-in-class and the worst-in-class portfolios represent respectively high-ranked and low-ranked portfolios according to KLD social ratings in each industry. $T$-statistics are in parenthesis. Sample alphas are annualized percentages. The regressions use Newey-West (1987) heteroskedasticity and autocorrelation consistent standard errors to calculate the significance levels for all coefficients.

\begin{tabular}{|c|c|c|c|c|c|c|}
\hline Portfolio & $\alpha(\%)$ & $R_{m}-R_{f}$ & $S M B$ & $H M L$ & $P Y 1 Y R$ & Adj $R^{2}$ \\
\hline $\begin{array}{l}\text { Best-in-class } \\
\text { (environment) }\end{array}$ & $\begin{array}{l}9.60^{* * *} \\
(2.81)\end{array}$ & $\begin{array}{l}0.97^{* * *} \\
(14.38)\end{array}$ & $\begin{array}{c}-0.32^{* * *} \\
(-3.37)\end{array}$ & $\begin{array}{c}-0.43^{* * *} \\
(-4.36)\end{array}$ & $\begin{array}{c}-0.19^{* * *} \\
(-3.33)\end{array}$ & 0.63 \\
\hline $\begin{array}{l}\text { Worst-in-class } \\
\text { (environment) }\end{array}$ & $\begin{array}{l}13.20^{* *} \\
(2.27)\end{array}$ & $\begin{array}{l}0.87^{* * *} \\
(5.77)\end{array}$ & $\begin{array}{c}0.05 \\
(0.29)\end{array}$ & $\begin{array}{l}-0.48^{* * *} \\
(-4.00)\end{array}$ & $\begin{array}{c}0.07 \\
(0.60)\end{array}$ & 0.36 \\
\hline Difference PF & $\begin{array}{l}-3.60 \\
(-0.54)\end{array}$ & $\begin{array}{c}0.10 \\
(0.63)\end{array}$ & $\begin{array}{l}-0.27^{* *} \\
(-2.29)\end{array}$ & $\begin{array}{c}0.05 \\
(0.27)\end{array}$ & $\begin{array}{l}-0.12^{*} \\
(-1.69)\end{array}$ & 0.07 \\
\hline $\begin{array}{l}\text { Best-in-class } \\
\text { (employee) }\end{array}$ & $\begin{array}{l}9.60^{* * * *} \\
(3.12)\end{array}$ & $\begin{array}{l}1.02^{* * *} \\
(12.68)\end{array}$ & $\begin{array}{l}-0.11 \\
(-0.99)\end{array}$ & $\begin{array}{l}-0.46^{* * *} \\
(-4.81)\end{array}$ & $\begin{array}{l}-0.07 \\
(-1.17)\end{array}$ & 0.67 \\
\hline $\begin{array}{l}\text { Worst-in-class } \\
\text { (employee) }\end{array}$ & $\begin{array}{l}4.80^{*} \\
(1.89)\end{array}$ & $\begin{array}{l}0.69^{* * *} \\
(7.63)\end{array}$ & $\begin{array}{c}0.24 \\
(0.27)\end{array}$ & $\begin{array}{c}0.05 \\
(0.38)\end{array}$ & $\begin{array}{l}-0.13^{*} \\
(-1.67)\end{array}$ & 0.48 \\
\hline Difference PF & $\begin{array}{l}4.80^{*} \\
(1.69)\end{array}$ & $\begin{array}{l}0.33^{* * *} \\
(2.83)\end{array}$ & $\begin{array}{l}-0.14 \\
(-1.40)\end{array}$ & $\begin{array}{l}-0.41^{* * *} \\
(-3.07)\end{array}$ & $\begin{array}{c}0.06 \\
(0.57)\end{array}$ & 0.21 \\
\hline $\begin{array}{l}\text { Best-in-class } \\
\text { (community) }\end{array}$ & $\begin{array}{l}7.20^{* *} \\
(2.11)\end{array}$ & $\begin{array}{l}0.89^{* * *} \\
(11.60)\end{array}$ & $\begin{array}{l}-0.10 \\
(-0.96)\end{array}$ & $\begin{array}{l}-0.32^{* * *} \\
(-4.73)\end{array}$ & $\begin{array}{l}-0.24^{* * *} \\
(-2.62)\end{array}$ & 0.64 \\
\hline $\begin{array}{l}\text { Worst-in-class } \\
\text { (community) }\end{array}$ & $\begin{array}{l}9.60^{* *} \\
(2.54)\end{array}$ & $\begin{array}{l}0.80^{* * *} \\
(7.80)\end{array}$ & $\begin{array}{l}0.38^{* * *} \\
(3.34)\end{array}$ & $\begin{array}{l}-0.28^{* * *} \\
(-3.53)\end{array}$ & $\begin{array}{l}-0.13 \\
(-1.20)\end{array}$ & 0.52 \\
\hline Difference PF & $\begin{array}{l}-2.40 \\
(-0.52)\end{array}$ & $\begin{array}{c}0.09 \\
(0.65)\end{array}$ & $\begin{array}{l}-0.48^{* * *} \\
(-3.67)\end{array}$ & $\begin{array}{l}-0.04 \\
(-0.47)\end{array}$ & $\begin{array}{l}-0.11 \\
(-1.27)\end{array}$ & 0.09 \\
\hline
\end{tabular}

Note: ${ }^{*}$ Significant at the 10 percent level. ${ }^{* *}$ Significant at the 5 percent level. ${ }^{* * *}$ Significant at the 1 percent level.

abnormal returns is $4.80 \%$ and the difference is statistically significant at the $10 \%$ level. The differences in SMB coefficients are mainly in favour of worst-in-class portfolios. The results show differences of -0.27 and -0.48 for the environment and community-sorted portfolios respectively; $t$-statistics show that the results are statistically significant at $10 \%$ and $1 \%$. Our results suggest that in service industry and based on the dimensions environment and community involvement, socially responsible companies seem to be tilted towards relatively large companies.

\subsection{The Effect of Market Conditions on the Relation Social-Financial Performance}

In order to verify the existence of the impact of the internet and financial crises on the results, we re-run the regressions with 2 dummy variables which respectively take the value 1 for internet crisis and credit crises and 0 otherwise. Tables 8-10 show respectively the results of the regressions with consideration for internet and credits crisis in industries A, B and C. First, we note that the abnormal returns of best-in-class portfolios are not significantly higher than those of worst-in-class portfolios in most cases. However, in industries A and B, the largest gap between the alphas was observed for "environment-sorted" portfolios. The gaps between the abnormal returns are $6.00 \%$ in industry A (Table 8 ) and $7.20 \%$ in industry B (Table 9). The results are statistically significant at $10 \%$ and $5 \%$ level respectively. Further, we notice that in industry C (Table 10), the largest gap between the alphas was observed for portfolios sorted based on the dimension "employee welfare". The difference between the abnormal returns is $7.20 \%$ and the result is statistically significant at $10 \%$ level. These findings could be explained by the fact that certain dimensions of corporate social responsibility may constitute a stronger signal relative to the other dimensions in some industries. The nature of the activities of mining and chemical companies is reputed to affect the environment. Therefore, the dimension environment may constitute a stronger signal compared to the other dimensions in this industry. Similarly, the public perception of a company is often influenced by whether or not it neglects its employees' welfare. Therefore, it is possible that in Service industry, the dimension "employee welfare" constitutes a stronger signal to the market and consequently has a more significant impact on financial performance. 
Table 8. Empirical results of four-factor regressions in Industry A with consideration for internet crisis and credit crises, January 1991 to December 2009. Best-in-class and the worst-in-class portfolios represent respectively high-ranked and lowranked portfolios according to KLD social ratings in each industry. $T$-statistics are in parenthesis. Sample alphas are annualized percentages. The regressions use Newey-West (1987) heteroskedasticity and autocorrelation consistent standard errors to calculate the significance levels for all coefficients.

\begin{tabular}{|c|c|c|c|c|c|c|c|c|}
\hline Portfolio & $\alpha(\%)$ & $R m-R f$ & $S M B$ & $H M L$ & PY1YR & I. crisis & C. crisis & $\operatorname{Adj} R^{2}$ \\
\hline $\begin{array}{l}\text { Best-in-class } \\
\text { (environment) }\end{array}$ & $\begin{array}{l}6.00^{* *} \\
(2.32)\end{array}$ & $\begin{array}{l}0.75^{* * *} \\
(10.40)\end{array}$ & $\begin{array}{l}-0.43^{* * *} \\
(-7.41)\end{array}$ & $\begin{array}{c}0.16 \\
(1.62)\end{array}$ & $\begin{array}{c}0.06 \\
(1.01)\end{array}$ & $\begin{array}{l}0.02^{* * *} \\
(3.85)\end{array}$ & $\begin{array}{l}0.01^{*} \\
(1.77)\end{array}$ & 0.49 \\
\hline $\begin{array}{l}\text { Worst-in-class } \\
\text { (environment) }\end{array}$ & $\begin{array}{c}0.00 \\
(0,23)\end{array}$ & $\begin{array}{l}0.71^{* * *} \\
(8.78)\end{array}$ & $\begin{array}{l}-0.39^{* * *} \\
(-3.95)\end{array}$ & $\begin{array}{c}0.22^{*} \\
(1.78)\end{array}$ & $\begin{array}{c}0.04 \\
(0.50)\end{array}$ & $\begin{array}{c}0.00 \\
(0.02)\end{array}$ & $\begin{array}{c}0.01 \\
(1.48)\end{array}$ & 0.40 \\
\hline Difference PF & $\begin{array}{l}6.00^{*} \\
(2.12)\end{array}$ & $\begin{array}{c}0.04 \\
(0.52)\end{array}$ & $\begin{array}{l}-0.04 \\
(-0.33)\end{array}$ & $\begin{array}{l}-0.06 \\
(-0.39)\end{array}$ & $\begin{array}{c}0.02 \\
(0.28)\end{array}$ & $\begin{array}{l}0.02^{* * *} \\
(4.44)\end{array}$ & $\begin{array}{c}0.00 \\
(0.14)\end{array}$ & 0.00 \\
\hline $\begin{array}{l}\text { Best-in-class } \\
\text { (employee) }\end{array}$ & $\begin{array}{l}6.00^{* * *} \\
(3.01)\end{array}$ & $\begin{array}{l}0.77^{* * *} \\
(9.12)\end{array}$ & $\begin{array}{l}-0.40^{* * *} \\
(-6.81)\end{array}$ & $\begin{array}{c}0.11 \\
(1.06)\end{array}$ & $\begin{array}{c}0.04 \\
(0.82)\end{array}$ & $\begin{array}{c}0.00 \\
(0.31)\end{array}$ & $\begin{array}{c}0.04 \\
(0.82)\end{array}$ & 0.58 \\
\hline $\begin{array}{l}\text { Worst-in-class } \\
\text { (employee) }\end{array}$ & $\begin{array}{c}3.60 \\
(1.41)\end{array}$ & $\begin{array}{l}0.85^{* * *} \\
(10.83)\end{array}$ & $\begin{array}{l}-0.16^{* *} \\
(-2.16)\end{array}$ & $\begin{array}{l}0.34^{* * * *} \\
(3.28)\end{array}$ & $\begin{array}{l}-0.01 \\
(-0.07)\end{array}$ & $\begin{array}{c}0.01 \\
(1.34)\end{array}$ & $\begin{array}{l}0.01^{*} \\
(1.96)\end{array}$ & 0.52 \\
\hline Difference PF & $\begin{array}{c}2.40 \\
(0.71)\end{array}$ & $\begin{array}{l}-0.08 \\
(-1.07)\end{array}$ & $\begin{array}{l}-0.24^{* *} \\
(-2.59)\end{array}$ & $\begin{array}{l}-0.23^{*} \\
(-1.80)\end{array}$ & $\begin{array}{c}0.05 \\
(0.78)\end{array}$ & $\begin{array}{l}-0.01 \\
(-1.12)\end{array}$ & $\begin{array}{c}0.00 \\
(0.48)\end{array}$ & 0.06 \\
\hline $\begin{array}{l}\text { Best-in-class } \\
\text { (community) }\end{array}$ & $\begin{array}{l}4.80^{* *} \\
(2.58)\end{array}$ & $\begin{array}{l}0.67^{* * *} \\
(7.83)\end{array}$ & $\begin{array}{l}-0.48^{* * *} \\
(-7.50)\end{array}$ & $\begin{array}{c}0.04 \\
(0.38)\end{array}$ & $\begin{array}{c}0.05 \\
(0.81)\end{array}$ & $\begin{array}{c}0.01 \\
(1.30)\end{array}$ & $\begin{array}{c}0.01 \\
(1.33)\end{array}$ & 0.49 \\
\hline $\begin{array}{l}\text { Worst-in-class } \\
\text { (community) }\end{array}$ & $\begin{array}{l}6.00^{* * *} \\
(2.65)\end{array}$ & $\begin{array}{l}0.81^{* * *} \\
(11.05)\end{array}$ & $\begin{array}{l}-0.38^{* * *} \\
(-3.79)\end{array}$ & $\begin{array}{c}0.20 \\
(1.44)\end{array}$ & $\begin{array}{c}0.05 \\
(0.72)\end{array}$ & $\begin{array}{c}0.00 \\
(1.38)\end{array}$ & $\begin{array}{l}0.01^{* *} \\
(2.13)\end{array}$ & 0.50 \\
\hline Difference PF & $\begin{array}{l}-2.20 \\
(-0.14)\end{array}$ & $\begin{array}{l}-0.14^{*} \\
(-1.69)\end{array}$ & $\begin{array}{l}-0.10 \\
(-0.72)\end{array}$ & $\begin{array}{l}-0.16 \\
(-0.97)\end{array}$ & $\begin{array}{c}0.00 \\
(0.03)\end{array}$ & $\begin{array}{c}0.01 \\
(1.10)\end{array}$ & $\begin{array}{c}0.00 \\
(0.18)\end{array}$ & 0.01 \\
\hline
\end{tabular}

Note: ${ }^{*}$ Significant at the 10 percent level. ${ }^{* *}$ Significant at the 5 percent level. ${ }^{* * *}$ Significant at the 1 percent level.

Table 9. Empirical results of four-factor regressions in Industry B with consideration for internet crisis and credit crises, January 1991 to December 2009. Best-in-class and the worst-in-class portfolios represent respectively high-ranked and lowranked portfolios according to KLD social ratings in each industry. $T$-statistics are in parenthesis. Sample alphas are annualized percentages. The regressions use Newey-West (1987) heteroskedasticity and autocorrelation consistent standard errors to calculate the significance levels for all coefficients.

\begin{tabular}{|c|c|c|c|c|c|c|c|c|}
\hline Portfolio & $\alpha(\%)$ & $R_{m}-R_{f}$ & $S M B$ & $H M L$ & PY1YR & I. crisis & C. crisis & $\operatorname{Adj} R^{2}$ \\
\hline $\begin{array}{l}\text { Best-in-class } \\
\text { (environment) }\end{array}$ & $\begin{array}{l}9.60^{* * *} \\
(3.50)\end{array}$ & $\begin{array}{l}1.03^{* * *} \\
(18.14)\end{array}$ & $\begin{array}{c}0.02 \\
(0.21)\end{array}$ & $\begin{array}{l}-0.35^{* * *} \\
(-5.51)\end{array}$ & $\begin{array}{l}-0.15^{* *} \\
(-2.58)\end{array}$ & $\begin{array}{c}0.01 \\
(1.42)\end{array}$ & $\begin{array}{c}-0.00 \\
(-0.21)\end{array}$ & 0.73 \\
\hline $\begin{array}{l}\text { Worst-in-class } \\
\text { (environment) }\end{array}$ & $\begin{array}{c}2.40 \\
(0.99)\end{array}$ & $\begin{array}{l}1.05^{* * *} \\
(27.55)\end{array}$ & $\begin{array}{c}0.01 \\
(0.02)\end{array}$ & $\begin{array}{l}0.58^{* * *} \\
(5.81)\end{array}$ & $\begin{array}{l}-0.19^{* * *} \\
(-2.76)\end{array}$ & $\begin{array}{c}0.01 \\
(1.26)\end{array}$ & $\begin{array}{c}0.01 \\
(1.13)\end{array}$ & 0.77 \\
\hline Difference PF & $\begin{array}{l}7.20^{* *} \\
(2.29)\end{array}$ & $\begin{array}{c}-0.02 \\
(-0.23)\end{array}$ & $\begin{array}{c}0.01 \\
(0.07)\end{array}$ & $\begin{array}{l}0.23^{* * *} \\
(7.23)\end{array}$ & $\begin{array}{c}0.04 \\
(0.34)\end{array}$ & $\begin{array}{c}0.00 \\
(0.01)\end{array}$ & $\begin{array}{c}0.01 \\
(0.09)\end{array}$ & 0.37 \\
\hline $\begin{array}{c}\text { Best-in-class } \\
\text { (employee) }\end{array}$ & $\begin{array}{l}8.40^{* * *} \\
(3.42)\end{array}$ & $\begin{array}{l}1.08^{* * *} \\
(29.47)\end{array}$ & $\begin{array}{l}0.10^{* *} \\
(2.08)\end{array}$ & $\begin{array}{l}-0.29^{* * *} \\
(-5.10)\end{array}$ & $\begin{array}{l}-0.08^{* * *} \\
(-2.69)\end{array}$ & $\begin{array}{c}0.00 \\
(0.07)\end{array}$ & $\begin{array}{c}0.00 \\
(0.94)\end{array}$ & 0.80 \\
\hline $\begin{array}{c}\text { Worst-in-class } \\
\text { (employee) }\end{array}$ & $\begin{array}{l}7.20^{* * *} \\
(2.90)\end{array}$ & $\begin{array}{l}1.02^{* * *} \\
(22.12)\end{array}$ & $\begin{array}{l}0.20^{* * *} \\
(3.42)\end{array}$ & $\begin{array}{c}0.09 \\
(1.16)\end{array}$ & $\begin{array}{l}-0.14^{* * *} \\
(-4.22)\end{array}$ & $\begin{array}{c}0.00 \\
(0.09)\end{array}$ & $\begin{array}{c}0.00 \\
(0.55)\end{array}$ & 0.80 \\
\hline Difference PF & $\begin{array}{c}1.20 \\
(0.38)\end{array}$ & $\begin{array}{c}0.06 \\
(1.23)\end{array}$ & $\begin{array}{c}-0.10 \\
(-0.10)\end{array}$ & $\begin{array}{l}-0.20^{* * *} \\
(-3.85)\end{array}$ & $\begin{array}{c}0.06 \\
(1.15)\end{array}$ & $\begin{array}{c}0.00 \\
(0.03)\end{array}$ & $\begin{array}{c}0.00 \\
(0.15)\end{array}$ & 0.13 \\
\hline $\begin{array}{l}\text { Best-in-class } \\
\text { (community) }\end{array}$ & $\begin{array}{l}4.80^{* *} \\
(2.39)\end{array}$ & $\begin{array}{l}0.94^{* * *} \\
(15.77)\end{array}$ & $\begin{array}{c}0.07 \\
(1.06)\end{array}$ & $\begin{array}{l}-0.12^{* *} \\
(-2.52)\end{array}$ & $\begin{array}{l}-0.17^{* * *} \\
(-3.87)\end{array}$ & $\begin{array}{c}0.01 \\
(1.25)\end{array}$ & $\begin{array}{c}0.01 \\
(1.37)\end{array}$ & 0.78 \\
\hline $\begin{array}{l}\text { Worst-in-class } \\
\text { (community) }\end{array}$ & $\begin{array}{l}8.40^{* *} \\
(2.55)\end{array}$ & $\begin{array}{l}1.09^{* * *} \\
(32.89)\end{array}$ & $\begin{array}{c}-0.00 \\
(-0.06)\end{array}$ & $\begin{array}{c}0.07 \\
(0.59)\end{array}$ & $\begin{array}{c}0.02 \\
(0.46)\end{array}$ & $\begin{array}{c}0.01 \\
(1.49)\end{array}$ & $\begin{array}{c}0.00 \\
(0.57)\end{array}$ & 0.75 \\
\hline Difference PF & $\begin{array}{c}-3.60 \\
(-0.89)\end{array}$ & $\begin{array}{l}-0.15^{* *} \\
(-2.34)\end{array}$ & $\begin{array}{c}0.07 \\
(0.85)\end{array}$ & $\begin{array}{c}-0.05 \\
(-1.25)\end{array}$ & $\begin{array}{c}-0.19^{* * *} \\
(-2.70)\end{array}$ & $\begin{array}{c}0.00 \\
(0.28)\end{array}$ & $\begin{array}{c}0.01 \\
(0.20)\end{array}$ & 0.07 \\
\hline
\end{tabular}

Note: ${ }^{*}$ Significant at the 10 percent level. ${ }^{* *}$ Significant at the 5 percent level. ${ }^{* * *}$ Significant at the 1 percent level. 
Table 10. Empirical results of four-factor regressions in Industry C with consideration for internet crisis and credit crises, January 1991 to December 2009. Best-in-class and the worst-in-class portfolios represent respectively high-ranked and lowranked portfolios according to KLD social ratings in each industry. $T$-statistics are in parenthesis. Sample alphas are annualized percentages. The regressions use Newey-West (1987) heteroskedasticity and autocorrelation consistent standard errors to calculate the significance levels for all coefficients.

\begin{tabular}{ccccccccc}
\hline Portfolio & $\alpha(\%)$ & $R_{m}-R_{f}$ & $S M B$ & $H M L$ & $P Y 1 Y R$ & $I$. crisis & C. crisis & Adj $R^{2}$ \\
\hline Best-in-class & $12.00^{* * *}$ & $0.95^{* * *}$ & $-0.30^{* * *}$ & $-0.39^{* * *}$ & $-0.19^{* * *}$ & $-0.02^{* *}$ & 0.00 & 0.63 \\
(environment) & $(3.09)$ & $(14.29)$ & $(-3.12)$ & $(-3.67)$ & $(-3.40)$ & $(-2.34)$ & $(0.02)$ & \\
Worst-in-class & 8.40 & $0.94^{* * *}$ & 0.01 & $-0.51^{* * *}$ & 0.07 & $0.03^{* * *}$ & 0.01 & 0.37 \\
(environment) & $(1.45)$ & $(6.60)$ & $(0.07)$ & $(-3.58)$ & $(0.59)$ & $(3.11)$ & $(0.93)$ & \\
Difference PF & 3.60 & 0.01 & $-0.29^{*}$ & 0.13 & $-0.26^{*}$ & $-0.05^{* * *}$ & -0.01 & 0.10 \\
& $(0.69)$ & $(0.07)$ & $(-1.94)$ & $(0.58)$ & $(-1.74)$ & $(-3.73)$ & $(-1.20)$ & \\
Best-in-class & $8.40^{* *}$ & $1.02^{* * *}$ & -0.11 & $-0.46^{* * *}$ & -0.07 & 0.00 & 0.00 & 0.67 \\
(employee) & $(2.42)$ & $(12.07)$ & $(-1.05)$ & $(-4.83)$ & $(-1.17)$ & $(0.29)$ & $(0.44)$ & \\
Worst-in-class & 1.20 & $0.75^{* * *}$ & 0.02 & 0.07 & -0.13 & $0.01^{*}$ & $0.02^{* * *}$ & 0.49 \\
(employee) & $(0.32)$ & $(8.63)$ & $(0.18)$ & $(0.54)$ & $(-1.55)$ & $(1.82)$ & $(2.78)$ & \\
& 7.20 & $0.27^{* *}$ & -0.13 & $-0.52^{* * *}$ & 0.06 & -0.01 & $-0.02^{*}$ & 0.21 \\
Difference PF & $(1.64)$ & $(2.34)$ & $(-1.28)$ & $(-3.38)$ & $(0.52)$ & $(-1.14)$ & $(-1.75)$ & \\
& 4.80 & $0.92^{* * *}$ & -0.11 & $-0.33^{* * *}$ & $-0.24^{* *}$ & 0.01 & 0.01 & 0.64 \\
Best-in-class & $(1.56)$ & $(12.24)$ & $(-1.17)$ & $(-3.75)$ & $(-2.59)$ & $(0.90)$ & $(1.32)$ & \\
(community) & 7.20 & $0.84^{* * *}$ & $0.38^{* * *}$ & $-0.27^{* * *}$ & -0.13 & 0.01 & 1.01 & 0.52 \\
Worst-in-class & $(1.62)$ & $(8.85)$ & $(3.17)$ & $(-3.00)$ & $(-1.15)$ & $(0.90)$ & $(1.21)$ & -1.00 \\
(community) & -2.40 & 0.06 & $0.27^{* * *}$ & -0.06 & -0.11 & 0.00 & 0.09 \\
Difference PF & $(-0.39)$ & $(0.56)$ & $(-3.68)$ & $(-0.67)$ & $(-1.28)$ & $(0.29)$ & $(-0.50)$ & 0.09 \\
\hline
\end{tabular}

Note: ${ }^{*}$ Significant at the 10 percent level. ${ }^{* *}$ Significant at the 5 percent level. ${ }^{* * *}$ Significant at the 1 percent level.

\subsection{Positive Relation between Social and Financial Performance versus Negative Relation between Social Irresponsibility and Financial Performance}

It has been suggested in the literature that social performance can be used by managers to neutralize the negative consequences of social irresponsibility on financial performance. In order to compare the negative relation between social irresponsibility and financial performance with the positive relation social-financial performance, we construct strength-sorted and concern-sorted portfolios. Based on average strength, we construct best-inclass (worst-in-class) portfolios with the highest (lowest) 25\% of companies and based on average concerns, we construct best-in-class (worst-in-class) portfolios with the lowest (highest) 25\% of companies.

Table 11 shows the results for strength-sorted and concern-sorted portfolios in industry A. The abnormal returns of best-in-class portfolios are not significantly higher than those of worst-in-class portfolios in most cases. However, the largest gaps between the alphas were observed between portfolios for the dimension environment and community involvement: $7.20 \%$ for concern-sorted portfolios in environment, $6.00 \%$ for concern-sorted portfolios in community involvement. The result for concern-sorted portfolios (environment) is statistically significant at $1 \%$ level. Our results confirm those of Walker and Howard (2002) who argued that, due to the nature of activities of mining sector and also numerous oppositions of environmental groups to their operations, the public has often a negative opinion of mining companies' environmental performance. Indeed, our finding could be explained by the fact that investors may be more concerned by not only the dimension environment but also by environmental irresponsibility rather than environmental performance of the companies who operate in the sector of mining and chemicals.

Table 12 shows the results for strength-sorted and concern-sorted portfolios in industry B. The abnormal returns of best-in-class portfolios are not significantly higher than those of worst-in-class portfolios in most cases. The largest gap between the alphas was observed between portfolios for the dimension environment and employee welfare: $7.20 \%$ for concern-sorted portfolios (environment), 3.60\% for strength-sorted portfolios (employee welfare). The result for concern-sorted portfolios (environment) is statistically significant at the $5 \%$ level. This result confirms those of Konar and Cohen (2001) who suggested that poor environmental performance seems to have a negative impact on the market values of manufacturing firms and consequently, environment seems to be an important source of concerns for the investors in manufacturing sector. 
Table 11. Empirical results of four-factor regressions in Industry A, dissociating Strengths and Concerns, January 1991 to December 2009. Best-in-class and the worst-in-class portfolios represent respectively high-ranked and low-ranked portfolios according to KLD social ratings in each industry. T-statistics are in parenthesis. Sample alphas are annualized percentages. The regressions use Newey-West (1987) heteroskedasticity and autocorrelation consistent standard errors to calculate the significance levels for all coefficients.

\begin{tabular}{|c|c|c|c|c|c|c|}
\hline Portfolio & $\alpha(\%)$ & $R_{m}-R_{f}$ & $S M B$ & $H M L$ & PY1YR & $\operatorname{Adj} R^{2}$ \\
\hline $\begin{array}{c}\text { Best-in-class } \\
\text { (environment, strengths) }\end{array}$ & $\begin{array}{l}6.00^{* * *} \\
(3.99)\end{array}$ & $\begin{array}{l}0.71^{* * *} \\
(14.18)\end{array}$ & $\begin{array}{l}-0.43^{* * *} \\
(-9.91)\end{array}$ & $\begin{array}{l}0.20^{* *} \\
(2.22)\end{array}$ & $\begin{array}{l}-0.06 \\
(-0.92)\end{array}$ & 0.68 \\
\hline $\begin{array}{c}\text { Worst-in-class } \\
\text { (environment, strengths) }\end{array}$ & $\begin{array}{l}8.40^{* * *} \\
(3.13)\end{array}$ & $\begin{array}{l}0.81^{* * * *} \\
(8.97)\end{array}$ & $\begin{array}{l}-0.21^{* * *} \\
(-3.01)\end{array}$ & $\begin{array}{l}0.22^{*} \\
(1.95)\end{array}$ & $\begin{array}{l}-0.11^{*} \\
(-1.68)\end{array}$ & 0.60 \\
\hline Difference PF & $\begin{array}{l}-2.40 \\
(-1.16)\end{array}$ & $\begin{array}{l}-0.10 \\
(-1.46)\end{array}$ & $\begin{array}{l}-0.22^{* * *} \\
(-3.08)\end{array}$ & $\begin{array}{l}-0.02 \\
(-0.19)\end{array}$ & $\begin{array}{l}-0.05 \\
(-0.12)\end{array}$ & 0.05 \\
\hline $\begin{array}{c}\text { Best-in-class } \\
\text { (environment, concerns) }\end{array}$ & $\begin{array}{c}12.00^{* * *} \\
(4.71)\end{array}$ & $\begin{array}{l}0.76^{* * *} \\
(8.52)\end{array}$ & $\begin{array}{l}-0.21^{* *} \\
(-2.28)\end{array}$ & $\begin{array}{c}0.05 \\
(0.38)\end{array}$ & $\begin{array}{l}-0.10 \\
(-1.29)\end{array}$ & 0.63 \\
\hline $\begin{array}{c}\text { Worst-in-class } \\
\text { (environment, concerns) }\end{array}$ & $\begin{array}{l}4.80^{* *} \\
(2.54)\end{array}$ & $\begin{array}{l}0.71^{* * *} \\
(12.37)\end{array}$ & $\begin{array}{l}-0.40^{* * *} \\
(-7.22)\end{array}$ & $\begin{array}{l}0.24^{* * *} \\
(3.43)\end{array}$ & $\begin{array}{l}-0.05 \\
(-0.59)\end{array}$ & 0.65 \\
\hline Difference PF & $\begin{array}{l}7.20^{* * *} \\
(3.09)\end{array}$ & $\begin{array}{l}-0.05 \\
(-0.88)\end{array}$ & $\begin{array}{l}-0.19^{*} \\
(-1.69)\end{array}$ & $\begin{array}{l}0.19^{*} \\
(1.83)\end{array}$ & $\begin{array}{c}0.05 \\
(0.60)\end{array}$ & 0.08 \\
\hline $\begin{array}{c}\text { Best-in-class } \\
\text { (employee, strengths) }\end{array}$ & $\begin{array}{l}7.20^{* * *} \\
(4.80)\end{array}$ & $\begin{array}{l}0.75^{* * *} \\
(10.81)\end{array}$ & $\begin{array}{l}-0.41^{* * *} \\
(-8.85)\end{array}$ & $\begin{array}{c}0.13 \\
(1.50)\end{array}$ & $\begin{array}{l}-0.08 \\
(-1.06)\end{array}$ & 0.70 \\
\hline $\begin{array}{c}\text { Worst-in-class } \\
\text { (employee, strengths) }\end{array}$ & $\begin{array}{l}9.60^{* * *} \\
(4.21)\end{array}$ & $\begin{array}{l}0.83^{* * *} \\
(17.85)\end{array}$ & $\begin{array}{l}-0.18^{* * *} \\
(-3.31)\end{array}$ & $\begin{array}{l}0.27^{* * *} \\
(2.90)\end{array}$ & $\begin{array}{l}-0.12 \\
(-1.44)\end{array}$ & 0.61 \\
\hline Difference PF & $\begin{array}{l}-2.40 \\
(-1.30)\end{array}$ & $\begin{array}{l}-0.08 \\
(-1.33)\end{array}$ & $\begin{array}{l}-0.24^{* * *} \\
(-3.65)\end{array}$ & $\begin{array}{l}-0.14^{* * *} \\
(-3.03)\end{array}$ & $\begin{array}{c}0.04 \\
(-0.39)\end{array}$ & 0.07 \\
\hline $\begin{array}{c}\text { Best-in-class } \\
\text { (employee, concerns) }\end{array}$ & $\begin{array}{l}8.40^{* * *} \\
(2.96)\end{array}$ & $\begin{array}{l}0.77^{* * *} \\
(9.73)\end{array}$ & $\begin{array}{l}-0.35^{* * *} \\
(-5.19)\end{array}$ & $\begin{array}{l}0.23^{* * *} \\
(3.19)\end{array}$ & $\begin{array}{c}-0.14 \\
(-1.59)\end{array}$ & 0.62 \\
\hline $\begin{array}{c}\text { Worst-in-class } \\
\text { (employee, concerns) }\end{array}$ & $\begin{array}{l}6.00^{* * * *} \\
(2.89)\end{array}$ & $\begin{array}{l}0.74^{* * *} \\
(14.32)\end{array}$ & $\begin{array}{l}-0.26^{* * *} \\
(-4.30)\end{array}$ & $\begin{array}{l}0.24^{* * *} \\
(3.28)\end{array}$ & $\begin{array}{l}-0.10 \\
(-1.44)\end{array}$ & 0.65 \\
\hline Difference PF & $\begin{array}{c}2.40 \\
(1.08)\end{array}$ & $\begin{array}{c}0.03 \\
(0.57)\end{array}$ & $\begin{array}{l}-0.09 \\
(0.90)\end{array}$ & $\begin{array}{l}-0.01 \\
(0.17)\end{array}$ & $\begin{array}{l}-0.04 \\
(0.33)\end{array}$ & 0.10 \\
\hline $\begin{array}{c}\text { Best-in-class } \\
\text { (community, strengths) }\end{array}$ & $\begin{array}{l}7.20^{* * *} \\
(4.51)\end{array}$ & $\begin{array}{l}0.67^{* * *} \\
(8.26)\end{array}$ & $\begin{array}{l}-0.45^{* * *} \\
(-8.36)\end{array}$ & $\begin{array}{l}0.07 \\
(0.88)\end{array}$ & $\begin{array}{l}-0.00 \\
(-0.07)\end{array}$ & 0.66 \\
\hline $\begin{array}{l}\text { Worst-in-class } \\
\text { (community, strengths) }\end{array}$ & $\begin{array}{l}9.60^{* * *} \\
(2.69)\end{array}$ & $\begin{array}{l}0.95^{* * *} \\
(13.89)\end{array}$ & $\begin{array}{l}-0.15^{* *} \\
(-2.00)\end{array}$ & $\begin{array}{c}0.25^{*} \\
(1.85)\end{array}$ & $\begin{array}{l}-0.19 \\
(-1.59)\end{array}$ & 0.61 \\
\hline Difference PF & $\begin{array}{l}-2.40 \\
(-0.47)\end{array}$ & $\begin{array}{l}-0.28^{* * *} \\
(-2.64)\end{array}$ & $\begin{array}{l}-0.30^{* * *} \\
(-3.80)\end{array}$ & $\begin{array}{l}-0.18 \\
(-1.40)\end{array}$ & $\begin{array}{l}-0.19 \\
(0.33)\end{array}$ & 0.16 \\
\hline $\begin{array}{c}\text { Best-in-class } \\
\text { (community, concerns) }\end{array}$ & $\begin{array}{l}13.20^{* * *} \\
(3.22)\end{array}$ & $\begin{array}{l}0.65^{* * *} \\
(6.31)\end{array}$ & $\begin{array}{l}-0.15 \\
(-1.46)\end{array}$ & $\begin{array}{c}0.17 \\
(1.17)\end{array}$ & $\begin{array}{l}-0.09 \\
(-0.87)\end{array}$ & 0.59 \\
\hline $\begin{array}{l}\text { Worst-in-class } \\
\text { (community, concerns) }\end{array}$ & $\begin{array}{l}6.00^{* *} \\
(2.45)\end{array}$ & $\begin{array}{l}0.74^{* * *} \\
(11.89)\end{array}$ & $\begin{array}{l}-0.28^{* *} \\
(-2.53)\end{array}$ & $\begin{array}{l}0.35^{* * *} \\
(3.11)\end{array}$ & $\begin{array}{l}-0.03 \\
(-0.37)\end{array}$ & 0.56 \\
\hline Difference PF & $\begin{array}{l}7.20 \\
(1.24)\end{array}$ & $\begin{array}{l}-0.09 \\
(1.07)\end{array}$ & $\begin{array}{c}0.13 \\
(0.90)\end{array}$ & $\begin{array}{l}-0.18 \\
(1.15)\end{array}$ & $\begin{array}{l}-0.06 \\
(0.71)\end{array}$ & 0.04 \\
\hline
\end{tabular}

Note: ${ }^{*}$ Significant at the 10 percent level. ${ }^{* *}$ Significant at the 5 percent level. ${ }^{* * *}$ Significant at the 1 percent level.

Table 13 presents the results for strength-sorted and concern-sorted portfolios in industry C. The abnormal returns of best-in-class portfolios are not significantly higher than those of worst-in-class portfolios in most cases. The largest gap between the alphas was observed between portfolios for the dimension community involvement and employee welfare: $5.60 \%$ for concern-sorted portfolios (community involvement), 3.60\% for strength-sorted portfolios (employee welfare). The result for community involvement is statistically significant at $1 \%$.

Table 14 summarizes the results of this study for portfolios based on aggregate dimensions as well as for strength-sorted and concern-sorted portfolios. 
Table 12. Empirical results of four-factor regressions in Industry B, dissociating Strengths and Concerns, January 1991 to December 2009. Best-in-class and the worst-in-class portfolios represent respectively high-ranked and low-ranked portfolios according to KLD social ratings in each industry. $T$-statistics are in parenthesis. Sample alphas are annualized percentages. The regressions use Newey-West (1987) heteroskedasticity and autocorrelation consistent standard errors to calculate the significance levels for all coefficients.

\begin{tabular}{|c|c|c|c|c|c|c|}
\hline Portfolio & $\alpha(\%)$ & $R_{m}-R_{f}$ & $S M B$ & $H M L$ & PY1YR & $\operatorname{Adj} R^{2}$ \\
\hline $\begin{array}{c}\text { Best-in-class } \\
\text { (Environment, Strengths) }\end{array}$ & $\begin{array}{l}8.40^{* * *} \\
(4.01)\end{array}$ & $\begin{array}{l}1.01^{* * *} \\
(26.66)\end{array}$ & $\begin{array}{c}0.05 \\
(1.13)\end{array}$ & $\begin{array}{l}-0.14^{* *} \\
(-2.13)\end{array}$ & $\begin{array}{l}-0.16^{* * *} \\
(-4.04)\end{array}$ & 0.79 \\
\hline $\begin{array}{c}\text { Worst-in-class } \\
\text { (Environment, Strengths) }\end{array}$ & $\begin{array}{l}10.80^{* * *} \\
(4.66)\end{array}$ & $\begin{array}{l}1.01^{* * *} \\
(27.55)\end{array}$ & $\begin{array}{c}0.05 \\
(0.89)\end{array}$ & $\begin{array}{l}-0.08 \\
(-1.19)\end{array}$ & $\begin{array}{c}0.02 \\
(0.69)\end{array}$ & 0.78 \\
\hline Difference PF & $\begin{array}{l}-2.40 \\
(-1.39)\end{array}$ & $\begin{array}{c}0.00 \\
(0.08)\end{array}$ & $\begin{array}{c}0.00 \\
(0.13)\end{array}$ & $\begin{array}{l}-0.06 \\
(-0.59)\end{array}$ & $\begin{array}{l}-0.18^{* * *} \\
(-4.84)\end{array}$ & 0.07 \\
\hline $\begin{array}{c}\text { Best-in-class } \\
\text { (Environment, Concerns) }\end{array}$ & $\begin{array}{l}12.00^{* * *} \\
(4.35)\end{array}$ & $\begin{array}{l}1.16^{* * *} \\
(31.70)\end{array}$ & $\begin{array}{l}0.12^{* *} \\
(2.00)\end{array}$ & $\begin{array}{l}-0.38^{* * *} \\
(-5.16)\end{array}$ & $\begin{array}{l}-0.08 \\
(-1.47)\end{array}$ & 0.76 \\
\hline $\begin{array}{c}\text { Worst-in-class } \\
\text { (Environment, Concerns) }\end{array}$ & $\begin{array}{l}4.80^{* * *} \\
(2.86)\end{array}$ & $\begin{array}{l}0.92^{* * *} \\
(22.80)\end{array}$ & $\begin{array}{c}0.01 \\
(0.09)\end{array}$ & $\begin{array}{l}0.37^{* * *} \\
(4.41)\end{array}$ & $\begin{array}{l}-0.13^{* * *} \\
(-3.57)\end{array}$ & 0.77 \\
\hline Difference PF & $\begin{array}{l}7.20^{* *} \\
(2.53)\end{array}$ & $\begin{array}{l}0.24^{* * *} \\
(-4.48)\end{array}$ & $\begin{array}{c}0.11 \\
(1.44)\end{array}$ & $\begin{array}{l}-0.01^{* * *} \\
(-6.41)\end{array}$ & $\begin{array}{c}0.05 \\
(0.69)\end{array}$ & 0.43 \\
\hline $\begin{array}{c}\text { Best-in-class } \\
\text { (Employee, Strengths) }\end{array}$ & $\begin{array}{c}10.80^{* * *} \\
(4.40)\end{array}$ & $\begin{array}{l}1.14^{* * *} \\
(20.05)\end{array}$ & $\begin{array}{l}0.20^{* * * *} \\
(3.02)\end{array}$ & $\begin{array}{l}-0.41^{* * *} \\
(-4.04)\end{array}$ & $\begin{array}{l}-0.20^{* * *} \\
(-2.72)\end{array}$ & 0.74 \\
\hline $\begin{array}{c}\text { Worst-in-class } \\
\text { (Employee, Strengths) }\end{array}$ & $\begin{array}{l}7.20^{* *} \\
(2.58)\end{array}$ & $\begin{array}{l}0.92^{* * *} \\
(14.76)\end{array}$ & $\begin{array}{c}0.07 \\
(1.15)\end{array}$ & $\begin{array}{c}0.12 \\
(1.59)\end{array}$ & $\begin{array}{l}-0.20^{* * *} \\
(-3.72)\end{array}$ & 0.69 \\
\hline Difference PF & $\begin{array}{c}3.60 \\
(1.23)\end{array}$ & $\begin{array}{l}0.22^{* * *} \\
(2.85)\end{array}$ & $\begin{array}{c}0.13 \\
(1.61)\end{array}$ & $\begin{array}{l}-0.33^{* * *} \\
(-4.09)\end{array}$ & $\begin{array}{c}0.00 \\
(0.01)\end{array}$ & 0.24 \\
\hline $\begin{array}{c}\text { Best-in-class } \\
\text { (Employee, Concerns) }\end{array}$ & $\begin{array}{l}8.40^{* * *} \\
(4.35)\end{array}$ & $\begin{array}{l}1.02^{* * *} \\
(26.58)\end{array}$ & $\begin{array}{l}0.10^{* *} \\
(2.09)\end{array}$ & $\begin{array}{l}-0.18^{* * *} \\
(-2.68)\end{array}$ & $\begin{array}{l}-0.06^{*} \\
(-1.87)\end{array}$ & 0.77 \\
\hline $\begin{array}{c}\text { Worst-in-class } \\
\text { (Employee, Concerns) }\end{array}$ & $\begin{array}{l}8.40^{* * *} \\
(4.45)\end{array}$ & $\begin{array}{l}1.00^{* * *} \\
(22.20)\end{array}$ & $\begin{array}{l}0.20^{* * *} \\
(3.25)\end{array}$ & $\begin{array}{l}-0.06 \\
(-0.69)\end{array}$ & $\begin{array}{l}-0.18^{* * *} \\
(-4.71)\end{array}$ & 0.81 \\
\hline Difference PF & $\begin{array}{c}0.00 \\
(0.02)\end{array}$ & $\begin{array}{c}0.02 \\
(0.37)\end{array}$ & $\begin{array}{l}-0.10 \\
(1.33)\end{array}$ & $\begin{array}{l}-0.12 \\
(1.13)\end{array}$ & $\begin{array}{l}0.12^{* *} \\
(-2.50)\end{array}$ & 0.04 \\
\hline $\begin{array}{c}\text { Best-in-class } \\
\text { (Community, Strengths) }\end{array}$ & $\begin{array}{l}6.00^{* * *} \\
(3.72)\end{array}$ & $\begin{array}{l}0.93^{* * *} \\
(20.75)\end{array}$ & $\begin{array}{c}0.07 \\
(1.16)\end{array}$ & $\begin{array}{c}-0.11^{* * *} \\
(-2.93)\end{array}$ & $\begin{array}{l}-0.15^{* * *} \\
(-3.73)\end{array}$ & 0.80 \\
\hline $\begin{array}{c}\text { Worst-in-class } \\
\text { (Community, Strengths) }\end{array}$ & $\begin{array}{l}8.40^{* * *} \\
(3.54)\end{array}$ & $\begin{array}{l}1.09^{* * *} \\
(15.84)\end{array}$ & $\begin{array}{l}0.20^{* * *} \\
(3.37)\end{array}$ & $\begin{array}{l}-0.16^{*} \\
(-1.71)\end{array}$ & $\begin{array}{l}-0.10^{*} \\
(-1.86)\end{array}$ & 0.72 \\
\hline Difference PF & $\begin{array}{l}-2.40 \\
(-0.73)\end{array}$ & $\begin{array}{l}-0.16^{* *} \\
(-2.02)\end{array}$ & $\begin{array}{l}-0.13 \\
(-1.43)\end{array}$ & $\begin{array}{c}0.05 \\
(0.55)\end{array}$ & $\begin{array}{l}-0.05 \\
(-0.08)\end{array}$ & 0.06 \\
\hline $\begin{array}{c}\text { Best-in-class } \\
\text { (Community, Concerns) }\end{array}$ & $\begin{array}{l}6.00^{*} \\
(1.81)\end{array}$ & $\begin{array}{l}1.05^{* * *} \\
(17.22)\end{array}$ & $\begin{array}{c}0.12 \\
(1.57)\end{array}$ & $\begin{array}{l}-0.24^{*} \\
(-1.74)\end{array}$ & $\begin{array}{l}-0.03 \\
(-0.39)\end{array}$ & 0.55 \\
\hline $\begin{array}{c}\text { Worst-in-class } \\
\text { (Community, Concerns) }\end{array}$ & $\begin{array}{c}3.60 \\
(1.39)\end{array}$ & $\begin{array}{l}0.95^{* * *} \\
(15.32)\end{array}$ & $\begin{array}{l}-0.09 \\
(-1.16)\end{array}$ & $\begin{array}{l}0.25^{* *} \\
(1.98)\end{array}$ & $\begin{array}{l}-0.07^{* *} \\
(-2.41)\end{array}$ & 0.60 \\
\hline Difference PF & $\begin{array}{l}2.40 \\
(0.75)\end{array}$ & $\begin{array}{c}0.10 \\
(0.93)\end{array}$ & $\begin{array}{c}0.21^{*} \\
(-1.96)\end{array}$ & $\begin{array}{l}-0.49^{* *} \\
(2.40)\end{array}$ & $\begin{array}{c}0.04 \\
(0.47)\end{array}$ & 0.13 \\
\hline
\end{tabular}

Note: ${ }^{*}$ Significant at the 10 percent level. ${ }^{* *}$ Significant at the 5 percent level. ${ }^{* * *}$ Significant at the 1 percent level.

\section{Conclusion}

This paper investigates the relation between individual dimensions of corporate social responsibility and financial performance in different industries. We have presented evidence that portfolios consisting of socially responsible companies based on the three dimensions of CSP (environment, employees' welfare and community involvement) and in the three industries (mining, manufacturing and services) do not under perform their conventional counterparts over the 1991-2009 period. Our study shows that there are possible financial gains in considering individual dimensions of corporate social performance in the investment process, or at least, there is no penalty associated with socially responsible investments based on the three social criteria in the three economic sectors. Moreover, our study suggests that individual dimensions of CSP constitute different signals in different industries. More specifically, our study shows that investors, based on the firms' nature of activities, 
Table 13. Empirical results of four-factor regressions in Industry C, dissociating Strengths and Concerns, January 1991 to December 2009. Best-in-class and the worst-in-class portfolios represent respectively high-ranked and low-ranked portfolios according to KLD social ratings in each industry. $T$-statistics are in parenthesis. Sample alphas are annualized percentages. The regressions use Newey-West (1987) heteroskedasticity and autocorrelation consistent standard errors to calculate the significance levels for all coefficients.

\begin{tabular}{|c|c|c|c|c|c|c|}
\hline Portfolio & $\alpha(\%)$ & $R_{m}-R_{f}$ & $S M B$ & $H M L$ & $P Y 1 Y R$ & $\operatorname{Adj} R^{2}$ \\
\hline $\begin{array}{c}\text { Best-in-class } \\
\text { (Environment, Strengths) }\end{array}$ & $\begin{array}{l}9.60^{* * * *} \\
(2.84)\end{array}$ & $\begin{array}{l}0.87^{* * *} \\
(13.29)\end{array}$ & $\begin{array}{l}-0.22^{* *} \\
(-2.09)\end{array}$ & $\begin{array}{l}-0.52^{* * *} \\
(-6.35)\end{array}$ & $\begin{array}{l}-0.33^{* * * *} \\
(-5.41)\end{array}$ & 0.67 \\
\hline $\begin{array}{c}\text { Worst-in-class } \\
\text { (Environment, Strengths) }\end{array}$ & $\begin{array}{c}13.20^{* * *} \\
(3.13)\end{array}$ & $\begin{array}{l}1.03^{* * *} \\
(9.42)\end{array}$ & $\begin{array}{l}-0.03 \\
(-0.12)\end{array}$ & $\begin{array}{l}-0.05 \\
(-0.42)\end{array}$ & $\begin{array}{l}-0.24^{* * *} \\
(-2.75)\end{array}$ & 0.44 \\
\hline Difference PF & $\begin{array}{l}-3.60 \\
(-1.15)\end{array}$ & $\begin{array}{l}-0.16 \\
(-1.14)\end{array}$ & $\begin{array}{l}-0.19 \\
(-0.83)\end{array}$ & $\begin{array}{c}-0.47^{* * *} \\
(-3.26)\end{array}$ & $\begin{array}{l}-0.09 \\
(-0.80)\end{array}$ & 0.04 \\
\hline $\begin{array}{c}\text { Best-in-class } \\
\text { (Environment, Concerns) }\end{array}$ & $\begin{array}{c}10.80^{* *} \\
(2.29)\end{array}$ & $\begin{array}{l}0.90^{* * *} \\
(6.70)\end{array}$ & $\begin{array}{c}0.08 \\
(0.39)\end{array}$ & $\begin{array}{l}-0.19 \\
(-1.41)\end{array}$ & $\begin{array}{l}-0.23^{* *} \\
(-2.26)\end{array}$ & 0.44 \\
\hline $\begin{array}{c}\text { Worst-in-class } \\
\text { (Environment, Concerns) }\end{array}$ & $\begin{array}{l}9.60^{* *} \\
(2.15)\end{array}$ & $\begin{array}{l}0.78^{* * *} \\
(6.65)\end{array}$ & $\begin{array}{l}-0.40^{* * *} \\
(-3.10)\end{array}$ & $\begin{array}{l}-0.45^{* * *} \\
(-5.28)\end{array}$ & $\begin{array}{l}-0.21^{* *} \\
(-2.30)\end{array}$ & 0.43 \\
\hline Difference PF & $\begin{array}{l}1.20 \\
(0.20)\end{array}$ & $\begin{array}{c}0.12 \\
(1.15)\end{array}$ & $\begin{array}{l}-0.32^{* *} \\
(-2.37)\end{array}$ & $\begin{array}{c}0.36^{*} \\
(-1.74)\end{array}$ & $\begin{array}{l}-0.02 \\
(0.19)\end{array}$ & 0.05 \\
\hline $\begin{array}{c}\text { Best-in-class } \\
\text { (Employee, Strengths) }\end{array}$ & $\begin{array}{c}10.80^{* * * *} \\
(3.22)\end{array}$ & $\begin{array}{l}0.96^{* * *} \\
(11.77)\end{array}$ & $\begin{array}{l}-0.19^{*} \\
(-1.78)\end{array}$ & $\begin{array}{l}-0.53^{* * * *} \\
(-8.15)\end{array}$ & $\begin{array}{l}-0.19^{* *} \\
(-2.41)\end{array}$ & 0.70 \\
\hline $\begin{array}{c}\text { Worst-in-class } \\
\text { (Employee, Strengths) }\end{array}$ & $\begin{array}{l}7.20^{* * *} \\
(2.34)\end{array}$ & $\begin{array}{l}0.93^{* * *} \\
(13.54)\end{array}$ & $\begin{array}{l}0.15^{* *} \\
(2.03)\end{array}$ & $\begin{array}{l}-0.20^{* * * *} \\
(-3.10)\end{array}$ & $\begin{array}{c}0.03 \\
(0.52)\end{array}$ & 0.65 \\
\hline Difference PF & $\begin{array}{c}3.60 \\
(1.11)\end{array}$ & $\begin{array}{c}0.03 \\
(0.02)\end{array}$ & $\begin{array}{l}-0.34^{* * *} \\
(-3.01)\end{array}$ & $\begin{array}{l}-0.33^{* * *} \\
(-3.52)\end{array}$ & $\begin{array}{l}-0.22^{* * *} \\
(-3.04)\end{array}$ & 0.13 \\
\hline $\begin{array}{c}\text { Best-in-class } \\
\text { (Employee, Concerns) }\end{array}$ & $\begin{array}{l}8.40^{* * * *} \\
(2.71)\end{array}$ & $\begin{array}{l}1.07^{* * *} \\
(18.46)\end{array}$ & $\begin{array}{l}-0.01 \\
(-0.08)\end{array}$ & $\begin{array}{l}-0.23^{* *} \\
(-2.46)\end{array}$ & $\begin{array}{c}0.01 \\
(0.18)\end{array}$ & 0.69 \\
\hline $\begin{array}{c}\text { Worst-in-class } \\
\text { (Employee, Concerns) }\end{array}$ & $\begin{array}{l}9.60^{* * *} \\
(2.85)\end{array}$ & $\begin{array}{l}0.85^{* * *} \\
(11.15)\end{array}$ & $\begin{array}{l}-0.06 \\
(-0.59)\end{array}$ & $\begin{array}{l}-0.16^{*} \\
(-1.77)\end{array}$ & $\begin{array}{l}-0.26^{* * * *} \\
(-3.14)\end{array}$ & 0.66 \\
\hline Difference PF & $\begin{array}{l}-1.20 \\
(0.09)\end{array}$ & $\begin{array}{l}0.22^{* * *} \\
(-3.17)\end{array}$ & $\begin{array}{c}0.05 \\
(0.52)\end{array}$ & $\begin{array}{l}-0.07 \\
(0.62)\end{array}$ & $\begin{array}{l}0.27^{* * *} \\
(-2.86)\end{array}$ & 0.13 \\
\hline $\begin{array}{c}\text { Best-in-class } \\
\text { (Community, Strengths) }\end{array}$ & $\begin{array}{l}7.20^{* *} \\
(2.02)\end{array}$ & $\begin{array}{l}0.84^{* * *} \\
(10.91)\end{array}$ & $\begin{array}{l}-0.12 \\
(-1.14)\end{array}$ & $\begin{array}{l}-0.35^{* * *} \\
(-4.94)\end{array}$ & $\begin{array}{l}-0.24^{* *} \\
(-2.35)\end{array}$ & 0.62 \\
\hline $\begin{array}{c}\text { Worst-in-class } \\
\text { (Community, Strengths) }\end{array}$ & $\begin{array}{l}9.60^{* *} \\
(2.55)\end{array}$ & $\begin{array}{l}0.94^{* * *} \\
(13.17)\end{array}$ & $\begin{array}{l}-0.11 \\
(-0.80)\end{array}$ & $\begin{array}{l}-0.10 \\
(-0.69)\end{array}$ & $\begin{array}{l}-0.02 \\
(-0.20)\end{array}$ & 0.47 \\
\hline Difference PF & $\begin{array}{l}-2.40 \\
(-0.58)\end{array}$ & $\begin{array}{l}-0.10 \\
(-1.10)\end{array}$ & $\begin{array}{l}-0.01 \\
(-0.13)\end{array}$ & $\begin{array}{l}-0.25 \\
(-1.38)\end{array}$ & $\begin{array}{l}-0.22^{* *} \\
(-1.98)\end{array}$ & 0.04 \\
\hline $\begin{array}{c}\text { Best-in-class } \\
\text { (Community, Concerns) }\end{array}$ & $\begin{array}{l}8.00^{* * * *} \\
(4.31)\end{array}$ & $\begin{array}{l}0.74^{* * *} \\
(4.90)\end{array}$ & $\begin{array}{l}0.55^{* * *} \\
(3.26)\end{array}$ & $\begin{array}{l}-0.07 \\
(-0.38)\end{array}$ & $\begin{array}{l}-0.11 \\
(-0.95)\end{array}$ & 0.50 \\
\hline $\begin{array}{c}\text { Worst-in-class } \\
\text { (Community, Concerns) }\end{array}$ & $\begin{array}{c}2.40 \\
(0.65)\end{array}$ & $\begin{array}{l}0.64^{* * *} \\
(7.95)\end{array}$ & $\begin{array}{c}0.15 \\
(1.41)\end{array}$ & $\begin{array}{l}-0.11 \\
(-0.96)\end{array}$ & $\begin{array}{l}-0.13 \\
(-1.26)\end{array}$ & 0.50 \\
\hline Difference PF & $\begin{array}{l}5.60^{* * *} \\
(3.61)\end{array}$ & $\begin{array}{c}0.10 \\
(0.48)\end{array}$ & $\begin{array}{l}0.40^{* *} \\
(1.99)\end{array}$ & $\begin{array}{c}0.04 \\
(0.20)\end{array}$ & $\begin{array}{c}0.02 \\
(0.10)\end{array}$ & 0.02 \\
\hline
\end{tabular}

Note: ${ }^{*}$ Significant at the 10 percent level. ${ }^{* *}$ Significant at the 5 percent level. ${ }^{* * *}$ Significant at the 1 percent level.

consider different aspects of corporate social responsibility in their decision-making process. Therefore, our results confirm those of Shalchian et al. (2012) and Derwall et al. (2005) who suggested that the relation social-financial performance tends not only to be industry-sensitive, but also appears to vary from one sector of industry to another. Our results also confirm those of Griffin and Mahon (1997) who argued that different industries face different configurations of stakeholders and consequently, investors may have different perceptions of CSP in different economic sectors.

Further, our findings suggest that, based on the firms' nature of activities, the dimension "environment" followed by "employee welfare" result in the largest positive gaps between the performances of social and conventional investments in the three industries. More specifically, environment seems to be an important social issue in mining and manufacturing sectors while employees' welfare seems to be the most important aspect of social responsibility in service industry. In fact, we find that in industries where companies' operations consist of 
Table 14. The summary of the results on "Differences" portfolios: The gaps between the alphas of Best-in-class and those of Worst-in-class portfolios. Alphas’ differences are annualized percentages.

\begin{tabular}{|c|c|c|c|}
\hline Dimension/Industry & Mining & Manufacturing & Services \\
\hline Environment & $\begin{array}{l}\text { AGG: } 2.40 \\
\text { STR: }-2.40 \\
\text { CON: } 7.20^{* * *}\end{array}$ & $\begin{array}{l}\text { AGG: } 7.20^{*} \\
\text { STR: }-2.40 \\
\text { CON: } 7.20^{* *}\end{array}$ & $\begin{array}{c}\text { AGG: }-3.60 \\
\text { STR: }-3.60 \\
\text { CON: } 1.20\end{array}$ \\
\hline Employee & $\begin{array}{l}\text { AGG: } 1.20 \\
\text { STR: }-2.40 \\
\text { CON: } 2.40\end{array}$ & $\begin{array}{l}\text { AGG: } 1.20 \\
\text { STR: } 3.60 \\
\text { CON: } 0.00\end{array}$ & $\begin{array}{c}\text { AGG: } 4.80^{*} \\
\text { STR: } 3.60 \\
\text { CON: }-1.20\end{array}$ \\
\hline Community & $\begin{array}{l}\text { AGG: } 0.00 \\
\text { STR: }-2.40 \\
\text { CON: } 7.20\end{array}$ & $\begin{array}{c}\text { AGG: }-2.40 \\
\text { STR: }-2.40 \\
\text { CON: } 2.40\end{array}$ & $\begin{array}{l}\text { AGG: }-2.40 \\
\text { STR: }-2.40 \\
\text { CON: } 5.60^{* * *}\end{array}$ \\
\hline
\end{tabular}

Note: AGG: The alphas difference based on Aggregate dimension (combination of strength and concerns). STR: The alphas difference based on Strengths. CON: The alphas difference based on Concerns.

extracting or transforming natural resources and also when companies' operations require a relatively high level of energy consumption, investors might be more concerned with environmental performance and consequently, consider environment protection as a relatively stronger signal. Furthermore, our results suggest that employee welfare constitutes a relatively stronger signal in wholesale, retail and service industries. In other words, employee welfare appears to be a main source of concern when the companies' nature of activities consists of "services". Moreover, when we control for the periods of internet and financial crises, we find that performance differentials become larger and more significant for the same dimensions in the same industries: environment in mining and manufacturing, employees' welfare in whole sales, retail and services. Our results confirm those of Shalchian et al. (2012) who suggested that the relation social-financial performance can be affected by different market conditions in different periods.

We have also assumed, in this paper, that investors consider companies' strengths (social performance) and concerns (social irresponsibility) separately in their process of decision making. Our results show that except for the dimension "employee welfare", the gaps between abnormal returns are larger for concern-sorted portfolios than those of strength-sorted portfolios in the three industries. Therefore, our results suggest that investors are more preoccupied by the additional risk caused by corporate social irresponsibility and the negative financial impact that it may cause than the positive impact of corporate social performance. In other words, for the dimensions environment and community involvement, investors consider social irresponsibility as a stronger signal pointing towards eventual financial losses for the investors in the future when for the dimension employees' welfare, they consider social performance as a stronger signal pointing towards eventual future financial gains.

\section{References}

Agle, B. R., \& Caldwell, C. B. (1999). Understanding Research on Values in Business: A Level of Analysis Framework. Business and Society, 38, 326-386. http://dx.doi.org/10.1177/000765039903800305

Aslaksen, I., \& Synnestvedt, T. (2003). Ethical Investment and the Incentives for Corporate Environmental Protection and Social Responsibility. Corporate Social Responsibility and Environmental Management, 10, 212-223. http://dx.doi.org/10.1002/csr.47

Bouslah, K., Kryzanowski, L., \& M'Zali, B. (2013). The Impact of the Dimensions of Social Performance on Firm Risk. Journal of Banking \& Finance, 37, 1258-1273. http://dx.doi.org/10.1016/j.jbankfin.2012.12.004

Calabrese, A., \& Lancioni, F. (2008). Analysis of Corporate Social Responsibility in Service Sector: Does Exist a Strategic Path? Knowledge and Process Management, 15, 107-125. http://dx.doi.org/10.1002/kpm.303

Carhart, M. M. (1997). On Persistence in Mutual Fund Performance. Journal of Finance, 52, 57-82. http://dx.doi.org/10.1111/j.1540-6261.1997.tb03808.x

Carter, R. C., Kale, R., \& Grimm, C. M., (2000). Environment Purchasing and Firm Performance: An Empirical Investigation. Journal of Transportation Research, 36, 219-228. http://dx.doi.org/10.1016/S1366-5545(99)00034-4

Chung, S. Y., Eneroth, K., \& Schneeweis, T. (2003). Corporate Reputation and Investment Performance: The U.K. and U.S. Experience. Research in International Business and Finance, 17, 273-291.

Cohen, M. A.; Fenn, S. A., \& Konar, S., (1997). Environmental and Financial Performance: Are They Related? Working Paper, Vanderbilt University, Nashville. 
Derwall, J., Guestner, N., Bauer, R., \& Koedijk, K. (2005). The Eco-Efficiency Premium Puzzle. The Financial Analysts Journal, 61, 51-61. http://dx.doi.org/10.2469/faj.v61.n2.2716

Diltz, D. J. (1995). Does Social Screening Affect Portfolio Performance? Journal of Investing, 4, 64-69. http://dx.doi.org/10.3905/joi.4.1.64

El Ghoul, S., Guedhami, O., Kwok, C. Y., \& Mishra, D. R. (2011). Does Corporate Social Responsibility Affect the Cost of Capital? Journal of Banking \& Finance, 35, 2388-2406. http://dx.doi.org/10.1016/j.jbankfin.2011.02.007

Fama, E. F., \& French, K. R. (1993). Common Risk Factors in the Returns on Stocks and Bonds. Journal of Financial Economics, 33, 3-56. http://dx.doi.org/10.1016/0304-405X(93)90023-5

Frooman, J. (1997). Socially Irresponsible and Illegal Behaviour and Shareholder Wealth: A Meta-Analysis of Event Studies. Business and Society, 36, 221-249. http://dx.doi.org/10.1177/000765039703600302

Galema, R., Plantinga, A., \& Scholtens, B. (2008). The Stock at Risk: The Return and Risk in Socially Responsible Investment. Journal of Banking \& Finance, 32, 2646-2654. http://dx.doi.org/10.1016/j.jbankfin.2008.06.002

Griffin, J. J., \& Mahon, J. F. (1997). The Corporate Social Performance and Corporate Financial Performance Debate: Twenty-Five Years of Incomparable Research. Business and Society, 36, 5-31. http://dx.doi.org/10.1177/000765039703600102

Guenster, N., Bauer, R., Derwall, J., \& Koedijk, K. (2010). The Economic Value of Corporate Eco-Efficiency. European Financial Management, 17, 679-704. http://dx.doi.org/10.1111/j.1468-036X.2009.00532.x

Hamilton, J. T. (1995). Pollution at News: Media and Stock Market Reactions to the Toxic Release Inventory Data. Journal of Environmental Economics and Management, 28, 98-113. http://dx.doi.org/10.1006/jeem.1995.1007

Heinze, D., Sibary, S., \& Sikula, A. (1999). Relation among Social Responsibility, Financial Soundness, and Investment Value in Manufacturing Industry Groups. Journal of Ethics and Behaviour, 9, 331-347. http://dx.doi.org/10.1207/s15327019eb0904_4

Hillman, A., \& Keim, G. D. (2001). Shareholder Value, Stakeholder Management, and Social Issues: What's the Bottom Line? Strategic Management Journal, 22, 125-139. http://dx.doi.org/10.1002/1097-0266(200101)22:2<125::AID-SMJ150>3.0.CO;2-H

Jenkins, H., \& Yakovleva, N. (2006). Corporate Social Responsibility in Mining Industry: Exploring Trends in Social and Environmental Disclosure. Journal of Cleaner Production, 14, 271-284. http://dx.doi.org/10.1016/j.jclepro.2004.10.004

Jones, R., \& Murrell, A. J. (2001). Signalling Positive Corporate Social Performance. Business and Society, 40, 59-78. http://dx.doi.org/10.1177/000765030104000105

Kempf, A., \& Osthoff, P. (2007). The Effect of Socially Responsible Investing on Portfolio Performance. European Financial Management, 13, 908-922. http://dx.doi.org/10.1111/j.1468-036X.2007.00402.X

Konar, S., \& Cohen, M. A. (1997). Information as Regulation: The Effect of Community Right to Know Laws on Toxic Emissions. Journal of Environmental Economics and Management, 32, 109-124. http://dx.doi.org/10.1006/jeem.1996.0955

Konar, S., \& Cohen, M. A. (2001). Does Market Value Environmental Performance? The Review of Economics and Statistics, 83, 281-289. http://dx.doi.org/10.1162/00346530151143815

Lanoie, P., Laplante, B., \& Roy, M. (1998). Can Capital Markets Create Incentives for Pollution Control? Ecological Economics, 26, 31-41. http://dx.doi.org/10.1016/S0921-8009(97)00057-8

Lin, H. L., Yang, H. L., \& Liou, D. Y. (2009). The Impact of Corporate Social Responsibility on Financial Performance: Evidence from Business in Taiwan. Technology in Society, 31, 56-63. http://dx.doi.org/10.1016/j.techsoc.2008.10.004

Mattingly, J. D., \& Berman, S. L. (2006). Measurement of Corporate Social Action: Discovering Taxonomy in the Kinder Lydenberg Domini Ratings Data. Business and Society, 45, 20-46. http://dx.doi.org/10.1177/0007650305281939

McGuire, J. B., Sundgren, A., \& Schneeweis, T. (1988). Corporate Social Responsibility and Firm Financial Performance. Academy of Management Journal, 31, 854-872. http://dx.doi.org/10.2307/256342

Moore, G. (2001). Corporate Social and Financial Performance: An Investigation in U.K. Supermarket Industry. Journal of Business Ethics, 34, 299-315. http://dx.doi.org/10.1023/A:1012537016969

Rehbein, K., Waddock, S. A., \& Graves, S. B. (2004). Understanding Shareholder Activism: Which Corporations Are Targeted? Business and Society, 43, 239-267. http://dx.doi.org/10.1177/0007650304266869

Rojas, M., M’zali, B., Turcotte, M. F., \& Merrigan, P. (2009). Bringing about Changes to Corporate Social Policy through Shareholder Activism: Filters, Issues, Targets and Success. Business and Society Review, 114, $217-252$.

http://dx.doi.org/10.1111/j.1467-8594.2009.00341.x

Roman, R. M., Hayibor, S., \&Agle, B. R. (1999). The Relation between Social and Financial Performance. Journal of Business Ethics, 38, 102-125. 
Shalchian, H., M’Zali, B., Elbadraoui, K., \& Lilti, J. J. (2012). On the Performance of Socially Responsible Investing: Further Evidence. Bankers, Markets and Investors, 112, 30-42.

Simpson, W. G., \& Kohers, T. (2002). The Link between Corporate Social and Financial Performance: Evidence from Banking Industry. Journal of Business Ethics, 35, 97-109. http://dx.doi.org/10.1023/A:1013082525900

Tebini, H. (2012). Relation between Financial and Social/Environmental Performance: A Critical Analysis. PhD Thesis, Montreal: University of Quebec.

Vance, S. (1975). Are Socially Responsible Corporations Good Investment Risks? Managerial Review, 64, 18-24.

Waddock, S., \& Graves, S. B. (1997). The Corporate Social Performance-Financial Performance Link. Strategic Management Journal, 18, 303-327. http://dx.doi.org/10.1002/(SICI)1097-0266(199704)18:4<303::AID-SMJ869>3.0.CO;2-G

Walker, J., \& Howard, S. (2002). Voluntary Codes of Conduct in Mining Industry. Minerals and Sustainable Development Project (MMSD).

Yakovleva, N. (2005). Corporate Social Responsibility in Mining Industry. Farnham: Ashgate Publications.

Yamashita, R. Miwaka, S. Sen, S., \& Roberts, M. C. (1999). The Rewards of Environmental Conscientiousness in the U.S. Capital Markets. Journal of Financial and Strategic Decisions, 12, 73-82. 